Camila de Rezende Barreto

Alometria reprodutiva e isotópica de tartaruga-verde Chelonia mydas (Linnaeus, 1758): relações entre tamanho corporal, dieta e investimento reprodutivo 
Universidade de São Paulo

Instituto de Biociências

Departamento de Ecologia

\title{
Alometria reprodutiva e isotópica de tartaruga-verde Chelonia mydas (Linnaeus, 1758): relações entre tamanho corporal, dieta e investimento reprodutivo
}

\author{
Camila de Rezende Barreto
}

\begin{abstract}
Dissertação apresentada ao Instituto de Biociências da Universidade de São Paulo, para obtenção de título de Mestre em Ciências, na Área de Ecologia

Orientador: Prof. Dr. Luciano Martins Verdade
\end{abstract}

São Paulo 


\section{Comissão Julgadora}

Prof(a). Dr(a)

Prof(a). Dr(a).

Prof(a). Dr(a)

Prof. Dr. Luciano Martins Verdade (Orientador) 
Aos meus pais, por me incentivarem a lutar pela liberdade em todos os âmbitos da vida. 
"O importante é que a nossa emoção sobreviva"

Paulo César Pinheiro 
Escrevo feliz meus agradecimentos e imensamente agradecida a muitas pessoas que de alguma forma andaram comigo nessa caminhada.

Primeiro quero agradecer aos meus pais, Silvia e Barreto, por me darem e mostrarem a vida no seu sentido mais amplo e heterogêneo. Por aguçarem em mim o senso de justiça e de luta, com amor. Mãe, obrigada pelo exemplo de vida, de força, de resistência e de amor. Você me transborda! Pai, sem seu incentivo certamente eu estaria longe da ciência. Sua capacidade de se manter em eterno movimento me arrebata. Obrigada! Ao meu irmão, Tiago, por ter me apresentado o laboratório de fisiologia de peixes, na UFSCar. Isso acendeu mais um fósforo em mim. À minha irmã Janaina por ser tão amiga, por ter me acolhido em São Paulo, feito mil correrias para me ajudar e por ter sido minha consultora em estatística e se envolvido tanto com o meu trabalho. Jana, você não existe. À minha irmã Julia por ser minha parceira de vida, e de toda a vida, e acreditar em mim e ser essa mulher intensa e cheia de amor. Ao amigo João pelas conversas tão ricas, serenas e sensatas que sempre me fazem crescer mais. Ao meu sobrinho Caetano, por transbordar meu coração de amor e tornar esse final de mestrado muito mais leve com seus sorrisos. À família da Vila do Amor, para mim sinônimo de amor, luta, resistência e acolhimento sem fim!

Agradeço ao meu orientador Luciano Verdade pela orientação e por ter acredito em mim e me incentivado tanto. Ao Comitê de Orientação Cecília Baptistotte, Eliana Matushima e Thiago Marques por me acompanharem, me orientarem e me ajudarem com as ideias. Vocês foram muito importantes para a realização desse trabalho. Às amigas do Laboratório de Ecologia Isotópica do CENA/USP, Janaina Leite e Luciana Mulero. Vocês me salvaram em tantos momentos e responderam tantas mensagens minhas que devem estar felizes por eu ter terminado. Rs. Ao Prof. Plínio Camargo e à querida Toninha pelas análises de isótopos das amostras.

Agradeço também ao Programa de Pós-graduação em Ecologia do IB/USP e à Vera por ter sido sempre atenciosa e me orientado com as burocracias. Ao colegas, professores e monitores da disciplina de Ecologia de Campo, pela experiência intensa de convivência e aprendizado sobre pesquisa, escrita e todos os questionamentos que a ciência envolve. Muito obrigada!

Um agradecimento muito especial ao querido amigo Jorge Guimarães, que abraçou a ideia da expedição à Ilha da Trindade de última hora, sem me conhecer. Passou 
noites e noites comigo, durante dois meses, andando na praia, tomando chuva, segurando tartaruga, marcando ninho, coletando tecidos e... cavando aqueles ninhos que não são brincadeira. Tudo isso para chegar do campo já de manhã e ainda processar os tecidos. Você é foda! Esteve junto durante os dois meses de trabalho intenso na ilha, sob desgaste físico, psicológico e militar. Rs. Mas também compartilhou cada momento incrível e inesquecível num lugar como aquele e com esses bichos sensacionais que são as tartarugas-verdes. Sua amizade, parceria e força me mantiveram firme e sã! MUITO obrigada!

À Flávia do TAMAR de Regência que, além de me ajudar no meu campo piloto em Regência, ainda me recebeu em sua casa. À Dani (Daniela Neris) por ter me ensinado a coletar sangue de tartaruga em tão pouco tempo, num campo piloto tão corrido, e ter sido tão ponta firme. Valeu demais, Dani. Você é um amor. Aos estagiários do TAMAR/ICMBio, Thaís, Vanessa e Douglas, que foram super parceiros em campo e dividiram os dias e a Estação Científica da Ilha da Trindade comigo. Além de cada trilha que fizemos juntos.

Aos amigos do Salve a Malandragem, por manterem sempre acesa a chama da vida e da amizade. Tão acesa que fica até difícil distinguir as duas coisas. À amiga de maloca, Eva Barros, por estar sempre tão perto mesmo tão longe e dividir comigo as experiências da vida. À amiga Fabiana Legnaro, pelas horas e horas intensas de conversas e trocas e por brindar sempre comigo. Você me inspira! Ao amigo Ronaldo FranciniFilho, por ter me ajudado com o resumo em inglês e com a revisão final da dissertação. Mas muito mais pelas conversas inspiradoras, pelo exemplo no posicionamento político frente às questões ambientais e pela amizade que já considero TANTO! Minha admiração por você. À amiga Claudete, que esteve presente nos momentos de cansaço, de tensão e todos os outros de descontração. Espero caminharmos livres pelas estradas da vida. À amiga Adriane Calaboni, que me incentivou desde o início dessa jornada e me recebeu tão bem no IB.

Esse trabalho não seria possível também sem o Programa de Pesquisas Científicas da Ilha da Trindade (PROTRINDADE), que ofereceu todo o apoio logístico de transporte até à Ilha, hospedagem e alimentação durante os dois meses de coleta de dados. Agradeço ao Comandante Costa Abrantes, que foi muito receptivo e prestativo com o meu projeto. Agradeço também à CAPES (Coordenação de Aperfeiçoamento de Pessoal de Nível Superior) pela bolsa concedida ao longo desses dois anos. 


\section{Índice}

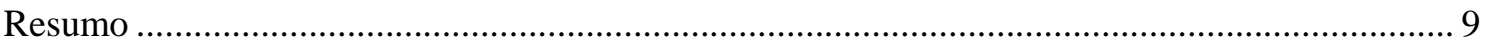

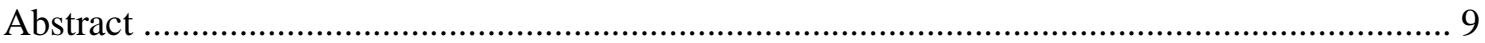

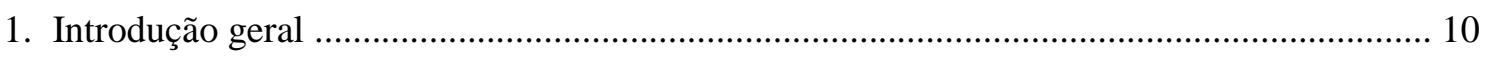

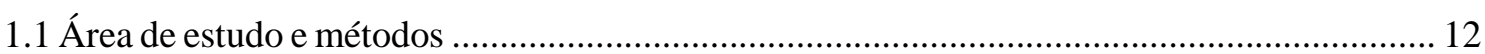

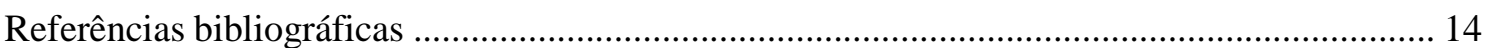

2 Alometria reprodutiva: influência do tamanho corporal no investimento reprodutivo de tartaruga-verde Chelonia mydas na Ilha da Trindade, Atlântico ocidental, com subsídios para o

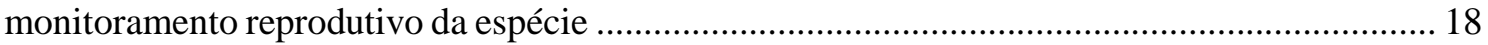

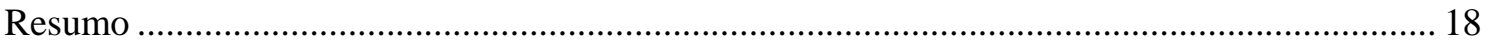

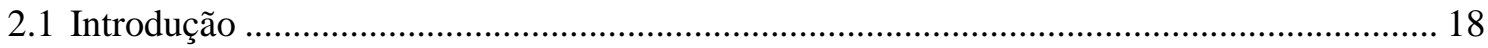

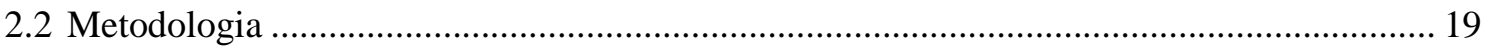

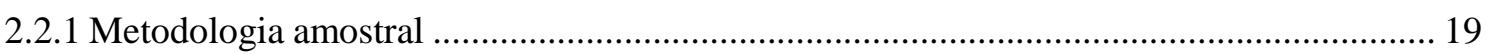

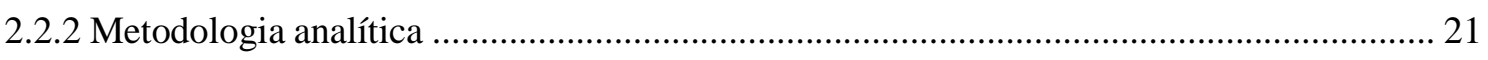

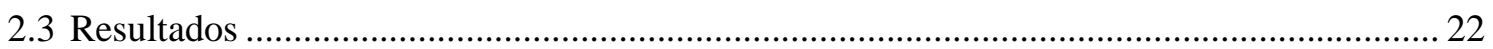

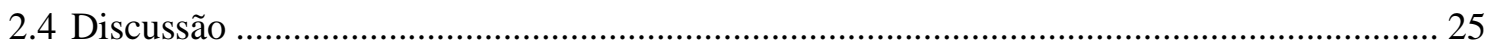

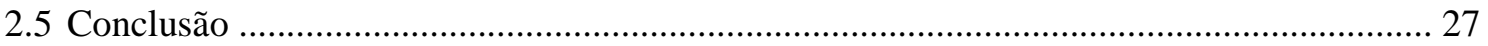

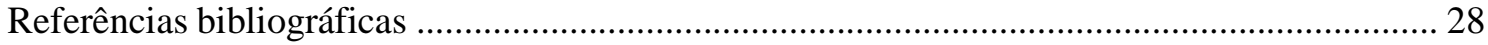

3 Alometria isotópica: influência da dieta no tamanho corporal e no investimento reprodutivo da tartaruga-verde Chelonia mydas na Ilha da Trindade, Atlântico ocidental .................................. 30

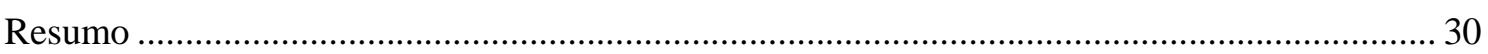

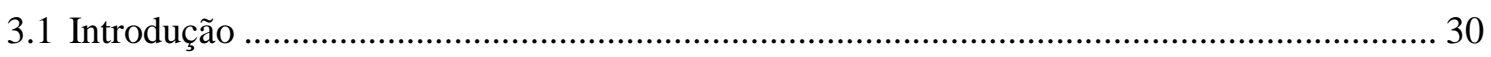

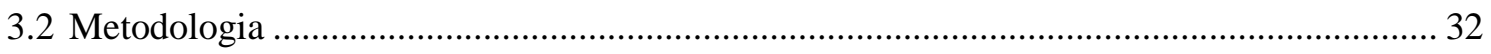

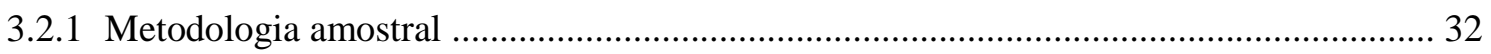

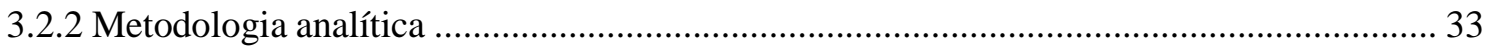

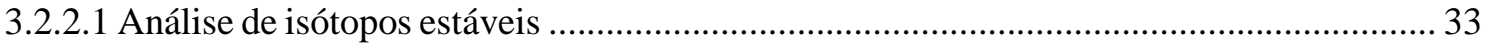

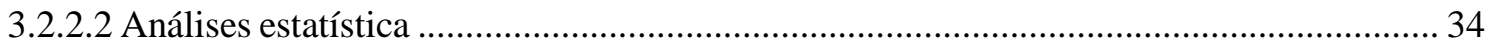

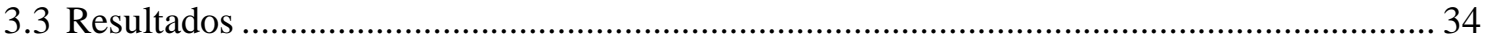

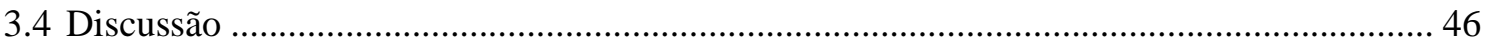

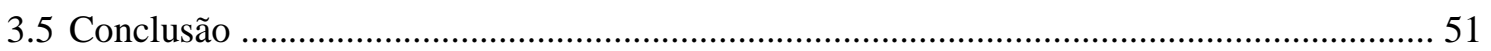

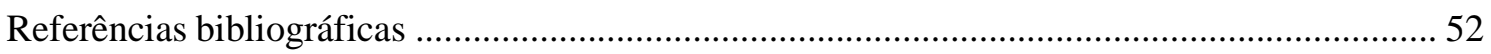

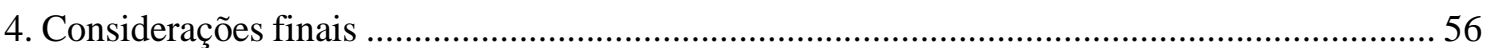




\section{Resumo}

As relações entre o tamanho dos indivíduos de uma espécie e suas consequências anatômicas, fisiológicas e ecológicas são denominadas relações alométricas. Nesse sentido, diversos trabalhos avaliam a influência do tamanho da fêmea de répteis em características relacionadas à sua reprodução, ao que chamamos de alometria reprodutiva. A variação no tamanho dos indivíduos de uma espécie e do investimento reprodutivo das fêmeas pode ser atribuída, dentre outros fatores, a diferenças na qualidade do alimento consumido. No presente estudo utilizamos medidas dos rastros, do tamanho do corpo, da ninhada e do ovo de tartaruga-verde, Chelonia mydas, para avaliar a influência do tamanho da fêmea no investimento reprodutivo. Realizamos também análise de isótopos estáveis de ${ }^{13} \mathrm{C}$ e ${ }^{15} \mathrm{~N}$ de diferentes tecidos das fêmeas para avaliar a influência da dieta (recente e antiga) no seu investimento reprodutivo. Coletamos os dados na Ilha da Trindade, principal área de nidificação da espécie em território brasileiro e situada no Sudoeste Atlântico, há aproximadamente $1140 \mathrm{~km}$ da costa central do Brasil. Verificamos que fêmeas de níveis tróficos mais altos, ou seja, que incluem itens alimentares de fonte animal em sua dieta, tendem a ser maiores e a produzirem maior quantidade de ovos. Foram estabelecidas equações para estimar o tamanho da fêmea a partir da largura de seu rastro e equações para estimar o tamanho da ninhada a partir do tamanho da fêmea, métricas que poderiam ajudar no monitoramento do sucesso reprodutivo de C. mydas na Ilha da Trindade.

\footnotetext{
Abstract

Allometric relationships describe anatomical, physiological and ecological variations according to body size The influence of size of females in reptiles in characteristics related to their reproduction, i.e. reproductive allometry, was evaluated is several papers. Variations in size of individuals of a given species and female's investment in reproduction may be attributed, among other factors, to differences in quality of consumed food. In the present study we have used data on turtle's track width, body size and clutch size of the green turtle Chelonia mydas to evaluate the influence of female's size on reproductive investment. We have also performed ${ }^{13} \mathrm{C}$ and ${ }^{15} \mathrm{~N}$ stable isotopes analysis of different body tissues of females to evaluate the influence of diet (recent and past) on reproductive investment. Data were collected in Trindade Island, the main nesting areas of C. mydas in the Brazilian territory, which is situated in the SW Atlantic, $1140 \mathrm{~km}$ away from the central coast of Brazil. We have verified that females from higher trophic levels, i.e. the ones including more food from animal origin in their diet, were bigger and produced larger clutches. Equations were build to estimate female's size from track width and clutch size from female's size. These metrics could help in the monitoring of the reproductive success of $C$. mydas in Trindade Island.
} 


\section{Introdução geral}

A história de vida de um organismo inclui todos os eventos que ocorrem desde sua concepção até sua morte, sendo os mais importantes o nascimento, a maturidade sexual, a reprodução e a morte (Peters 1986). Há um conjunto de hipóteses que fazem predições de fenômenos biológicos relacionados com mudanças no tamanho do corpo. Segundo Peter (1986), essas hipóteses podem ser traduzidas em diversas equações que relacionam características de um animal com seu tamanho corporal. Relações alométricas são definidas num sentido amplo como relações entre variações no tamanho e suas consequências anatômicas, fisiológicas e ecológicas. Essas relações podem influenciar e ser influenciadas por adaptações ecológicas (Gould 1966; Rosalino et al. 2013).

Diversos trabalhos têm avaliado relações entre tamanho do corpo e de partes dele (e.g., Verdade 2000) e relações de tamanho do corpo com parâmetros biológicos tais como taxa de consumo de oxigênio, taxas metabólicas na ingestão de alimentos, fecundidade e idade de maturidade sexual. Outros estudos relacionam o tamanho da fêmea de répteis com características de tamanho da ninhada e de seus ovos e filhotes, ao que chamamos aqui de alometria reprodutiva, ou ainda com o investimento maternal na produção da prole (Bjorndal \& Carr 1989; Pinckney 1990; Verdade 2001; Broderick et al. 2003; Cantarelli 2006; Wallace et al. 2006).

A estratégia de reprodução de um táxon pode incluir diversos aspectos. Informações sobre quantidade e tamanho dos descendentes podem ser facilmente obtidas dependendo do táxon. As estratégias podem incluir, por exemplo, ninhadas com maior número de ovos e/ou ninhadas com ovos maiores. Ovos maiores produzem filhotes maiores que tem maiores chances de sobrevivência (Van Buskirk \& Crowder 1994; Cheng et al. 2009). Para diversos grupos animais isso pode ser influenciado por um trade-off direto (considerando limites finitos de energia da mãe) e/ou por outras vias que podem operar no momento da incubação dos ovos (e.g., competição entre irmãos por recursos limitados, tais como água e oxigênio) ou até mesmo depois de sua eclosão (e.g., vantagem de ninhadas maiores em relação à predação) (Brown \& Shine 2009). Estudos nesse sentido são escassos no que se refere às tartarugas marinhas. Avaliações das relações entre o tamanho de fêmeas de tartarugas marinhas, o tipo e qualidade da dieta e o sucesso reprodutivo são ainda pouco conhecidas (e.g., Hatase et al. 2014; Vander Zanden et al. 2014;).

As tartarugas marinhas são quelônios originados no final do Triássico, há mais de 200 milhões de anos (Lutz \& Musick 1997). Apesar de terem resistido a drásticas mudanças climáticas, encontram-se ameaçadas devido a diversos fatores como perda de hábitats, poluição, coleta dos ovos, matança das fêmeas, pesca incidental e doenças (Baptistotte 2007). Atualmente, existem no mundo sete espécies de tartarugas marinhas. Dessas, cinco ocorrem em águas brasileiras e estão classificadas, nacional e internacionalmente, como ameaçadas. De acordo com a Lista Nacional Oficial de Espécies da Fauna Ameaçadas de Extinção, a tartaruga-verde 
(Chelonia mydas) encontra-se na categoria vulnerável (MMA 2014) e, de acordo com a International Union for Conservation of Nature (IUCN), na categoria em perigo (IUCN 2015).

Filhotes de tartaruga-verde vivem seus primeiros anos de vida em ambientes oceânicos, apresentando uma dieta onívora e com forte tendência à carnivoria (Bjorndal 1985). Por muito tempo aceitou-se a ideia de que, após esse primeiro estágio de vida, esses animais passam a viver em ambientes neríticos, onde mudam para uma dieta basicamente herbívora (Bjorndal 1997). No entanto, recentemente, por meio de análises de isótopos estáveis e monitoramento de fêmeas com telemetria por satélite, alguns estudos têm sugerido que essa mudança de hábitat é facultativa e, consequentemente, a alteração da dieta também (i.e., Hatase et al. 2006).

A plasticidade no uso do hábitat e na dieta pode resultar em diferenças, sob diversos aspectos, entre os indivíduos de uma mesma espécie. Trabalhos realizados com fêmeas reprodutoras de tartaruga-cabeçuda (Caretta caretta) verificaram diferenças no tamanho das fêmeas reprodutoras e do número de ovos por ninhada (Zbinden et al. 2011; Hatase et al. 2002) de acordo com a área em que elas se alimentavam. Os autores sugerem que essa variação no tamanho dos indivíduos ocorre por causa de diferenças na qualidade nutricional do alimento consumido.

Em um estudo sobre o lagarto Anolis sagrei, a diminuição de alimento disponível para as fêmeas acarretou em diminuição da gema dos ovos e afetou negativamente o tamanho, crescimento e sobrevivência dos filhotes. Isso mostra que o "ambiente materno" pode afetar o fitness dos filhotes (e.g., seu tamanho corpóreo) por meio de um efeito indireto sobre o investimento nas gemas. Nesse caso, é ressaltado o conjunto complexo de efeitos indiretos por meio do qual os efeitos maternos podem operar (Warner \& Lovern 2014).

O uso de isótopos estáveis em estudos de dieta animal é baseado no fato de que o tecido animal reflete a proporção isotópica do alimento consumido (Marques et al. 2014b). Os elementos naturais presentes na dieta de um animal são incorporados aos seus tecidos. As proporções de isótopos estáveis pesados e leves desses elementos (e.g., Carbono) diferem de um organismo para outro. Devido ao seu metabolismo, quando um animal consome um determinado organismo, há um enriquecimento ou empobrecimento do isótopo pesado em seus tecidos em relação a esse organismo, ou seja, à sua dieta. À medida que a matéria passa de um nível trófico para outro há, então, uma mudança nas proporções desses isótopos. Dessa forma, é possível identificar os níveis tróficos dos indivíduos amostrados através da análise de seus tecidos. A composição isotópica de tecidos de baixa atividade metabólica, como a epiderme e a queratina, é reflexo da dieta de longoprazo do animal (DeNiro \& Epstein 1978, 1981). Já a composição dos tecidos de metabolismo mais acelerado, como o sangue, reflete a dieta recente do organismo. Na natureza, os diferentes ambientes também diferem nas proporções de isótopos estáveis dos elementos naturais (e.g., C, N, O, H e S), já que os processos biogeoquímicos diferem em cada um deles (Ceriani et al. 2014). Dessa forma, a composição isotópica dos tecidos dos animais migradores reflete a dieta 
consumida e, consequentemente, o ambiente onde isso ocorreu. A análise de isótopos estáveis fornece, então, uma vantagem ao permitir a avaliação das tendências ecológicas de curto e longo prazo, necessária para os planos de gestão e conservação das espécies selvagens (Marques et al. 2014a).

Este estudo teve como objetivos avaliar as relações de tamanho corporal de fêmeas de $C$. mydas com seus rastros nas praias de nidificação e com características de sua reprodução (capítulo 2) e avaliar a relação do nível trófico dessas fêmeas com seu tamanho corporal e com características de sua reprodução (capítulo 3).

Para a realização deste estudo foi necessária a coleta de dados referentes às fêmeas de tartaruga-verde e aos seus ninhos numa área de nidificação da espécie. Dessa forma, monitoramos duas praias na Ilha da Trindade, uma ilha remota no oceano Atlântico, afastada a quase $1140 \mathrm{~km}$ da costa central do Brasil. Para chegar até o local, foram necessários três dias de viagem, partindo da cidade do Rio de Janeiro, RJ, a bordo de um navio da Marinha do Brasil. A Ilha da Trindade é a área com maior número de fêmeas de C. mydas em nidificação no Brasil (Almeida et al. 2011). $\mathrm{O}$ monitoramento foi feito durante dois meses, sempre à noite, intercalando entre as duas praias (Andradas e Tartarugas).

As tartarugas-verdes são animais marinhos de grande porte. As fêmeas adultas que nidificam na Ilha da Trindade estão entre as maiores relatadas para populações da espécie: média de 115,2 cm de comprimento curvilíneo da carapaça (Almeida et al. 2011). São animais fortes, robustos e de difícil contenção. Apesar disso, quando sobem para nidificarem na areia da praia, sua locomoção é relativamente lenta e é possível manipulá-las e extrair delas diversas informações. No entanto, algumas dessas informações, para serem obtidas, demandam cuidado e paciência a fim de aguardar o momento adequado e propício, quando o animal estiver menos agitado.

\section{1 Área de estudo e métodos}

Em território brasileiro, há três principais áreas de nidificação de C. mydas, todas em ilhas oceânicas: Ilha da Trindade, Atol das Rocas e Fernando de Noronha. A Ilha da Trindade é o maior sítio reprodutivo de tartaruga-verde no Brasil, abrigando ninhos em nove praias diferentes. Os dados foram coletados em duas praias (Tartarugas e Andradas) da Ilha da Trindade (Brasil), localizada no oceano Atlântico, na porção leste da grande cadeia vulcânica submarina VitóriaTrindade (20³0'S e $29^{\circ} 20^{\prime} \mathrm{W}$ ) (Figura 1.1). Distando aproximadamente $1.140 \mathrm{~km}$ da costa do estado do Espírito Santo (Sudeste do Brasil) e $48 \mathrm{~km}$ a oeste do Arquipélago de Martin Vaz (de Paula Clemente et al. 2009), a ilha possui uma área de $13,5 \mathrm{~km}^{2}$ e é formada por rochas vulcânicas e subvulcânicas (Almeida 2002). O litoral possui recifes rochosos esparsamente recobertos por algas calcárias e corais (Pereira-Filho et al. 2011), com praias e dunas estreitas. Há barreiras rochosas que dificultam o acesso das fêmeas às praias (Almeida et al. 2011), sendo possível 
encontrar fêmeas encalhadas e/ou machucadas. Uma média anual de 3600 ninhos (média de 120 ovos por ninho) faz da ilha a sétima colônia de nidificação da espécie no Atlântico (de Padua Almeida et al. 2011). A ilha fica sob guarda da Marinha do Brasil (Mohr et. al. 2009) e seu acesso é restrito a militares da Marinha e pesquisadores.

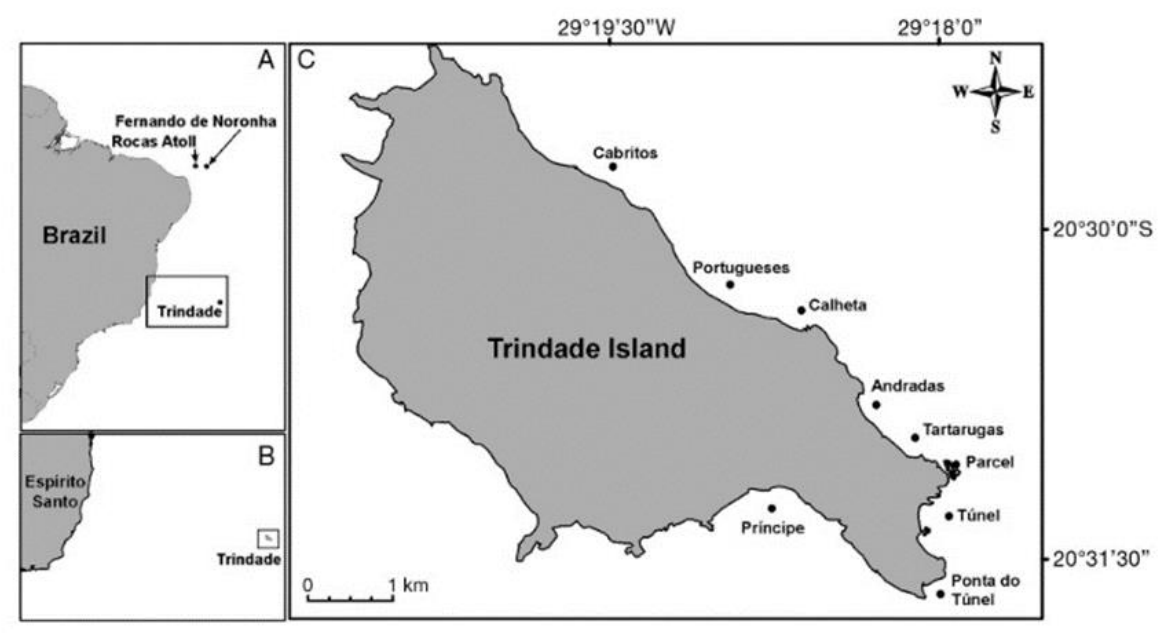

Figura 1.1 Localização da Ilha da Trindade no Oceano Atlântico com a localização das praias de nidificação de $C$. mydas na ilha. Fonte: Almeida et al. (2011).

Para obter os dados referentes às fêmeas, foi realizada biometria e a coleta de tecidos corporais para posterior análise de isótopos estáveis. A biometria é um processo rápido, fácil, sem necessidade de contenção do animal e realizado com uma fita métrica. Devem ser tomados os devidos cuidados para que o pesquisador não seja acertado por suas nadadeiras, sobretudo as dianteiras. A coleta dos tecidos (i.e.; sangue, epiderme, queratina da carapaça, unha e queratina da nadadeira) demanda certa contenção do animal. A coleta do sangue, por exemplo, é realizada com uma agulha grande, de $40 \times 1,20 \mathrm{~mm}$, e é preciso que o animal esteja contido para evitar acidentes tanto com o animal quanto com o pesquisador. A coleta dos outros tecidos (epiderme e queratina da carapaça e da nadadeira) exige o uso de punch e bisturi, materiais altamente cortantes e, assim como a coleta de sangue, exige contenção do animal para evitar acidentes potencialmente graves.

Toda a coleta dos tecidos das fêmeas foi realizada por duas pessoas em campo, um pesquisador e um estagiário. Como já mencionado, a tartaruga-verde é um animal forte e apenas uma pessoa não é suficiente para imobilizá-la. Desta forma, apenas uma contenção parcial do animal foi possível. Para isso, é necessário tempo, planejamento e atenção para entender o ritmo do animal, e perceber o melhor momento de iniciar a coleta e o momento de interrompê-la também. Por exemplo, quando a tartaruga começa a se agitar demais, sobretudo no momento da coleta do sangue, é preciso esperar que ela se acalme. Chelonia mydas, quando estressada, muitas vezes movimenta a cabeça de forma intensa. Como a agulha é introduzida na região cervical, é 
necessário que se aguarde um momento em que o indivíduo não esteja realizando movimentos muito bruscos.

Para esse tipo de trabalho, é imprescindível conhecer o comportamento do objeto de estudo. O estresse ao animal será inevitável, mas é possível e desejável atenua-lo. Por exemplo, no momento em que a fêmea está ainda fechando ou já compactando seu ninho, com as nadadeiras traseiras, dificilmente ela sairá de onde está. No entanto, não pareceu ser a melhor ocasião para intervirmos, já que esse é um momento muito importante a ela: o de proteger e esconder seus ovos. Isso geraria um estresse provavelmente ainda maior. Por isso, sempre aguardávamos o encerramento da postura. Notamos, também, que durante a coleta dos tecidos, enquanto contínhamos suas nadadeiras dianteiras, em alguns momentos a tartaruga inspirava ar e logo após se debatia muito. Então, sempre que ela inspirava, interrompíamos a coleta até o momento em que ela diminuísse seus movimentos.

Em pesquisas de campo sempre há imprevistos. É difícil planejar todos os detalhes, sobretudo numa área como a Ilha da Trindade, onde o navio deixa a tripulação e volta, geralmente, dois meses depois para buscá-la. Por isso, além de uma boa revisão na literatura sobre trabalhos semelhantes, é importante conversar com pessoas que trabalham com o mesmo objeto de estudo e que já façam coletas parecidas. Dados exclusivamente da literatura não são suficientes para se realizar uma coleta eficiente e que atenue o estresse, inevitável, ao animal. Tempo, paciência e muita observação em campo, a fim de se conhecer o "jeitão do bicho", certamente são decisivos para o sucesso do trabalho.

\section{Referências bibliográficas}

Almeida, A.P., Moreira, L.M.P., Bruno S.C., Thomé, J.C.A., Martins, A.S., Bolten, A.B., Bjorndal, K.A. (2011) Green turtle nesting on Trindade Island, Brazil: abundance, trends, and biometrics. Endang Species Res 14:193-201.

Almeida, F. F. D. (2002). Ilha de Trindade: Registro de vulcanismo cenozóico no Atlântico Sul. SCHOBBENHAUS, C.; CAMPOS, DA; QUEIROZ, ET, WINGE, M, 369-377.

Baptistotte, C. (2007). Caracterização espacial e temporal da fibropapilomatose em tartarugas marinhas da costa brasileira (Doctoral dissertation, Universidade de São Paulo).

Bjorndal, K. A. (1985). Nutritional ecology of sea turtles. Copeia, 736-751.

Bjorndal, K. A., \& Carr, A. (1989). Variation in clutch size and egg size in the green turtle nesting population at Tortuguero, Costa Rica. Herpetologica, 181-189.

Bjorndal, K. A. (1997). Foraging ecology and nutrition of sea turtles. The biology of sea turtles, 1, 199-231.

Broderick, A. C., Glen, F., Godley, B. J., \& Hays, G. C. (2003). Variation in reproductive output of marine turtles. Journal of Experimental Marine Biology and Ecology, 288(1), 95-109. 
Brown, G. P., \& Shine, R. (2009). Beyond size-number trade-offs: clutch size as a maternal effect. Philosophical Transactions of the Royal Society B: Biological Sciences, 364(1520), 1097-1106.

Cantarelli, V. H. (2006). Alometria reprodutiva da tartaruga-da-Amazônia (Podocnemis expansa): bases biológicas para o manejo (Doctoral dissertation, Universidade de São Paulo).

Ceriani, S. A., Roth, J. D., Ehrhart, L. M., Quintana-Ascencio, P. F., \& Weishampel, J. F. (2014). Developing a common currency for stable isotope analyses of nesting marine turtles. Marine biology, 161(10), 2257-2268.

Cheng, I. J., Huang, C. T., Hung, P. Y., Ke, B. Z., Kuo, C. W., \& Fong, C. L. (2009). Ten years of monitoring the nesting ecology of the green turtle, Chelonia mydas, on Lanyu (Orchid Island), Taiwan. Zoological Studies, 48(1), 83-94.

de Paula Clemente, E., Schaefer, C. E. G., Oliveira, F. S., Albuquerque Filho, M. R., Válka, R., \& Corrêa, G. R. (2009). Topossequência de solos na ilha da Trindade, Atlântico Sul. Revista Brasileira de Ciência do Solo, 33(5).

DeNiro, M. J., \& Epstein, S. (1978). Influence of diet on the distribution of carbon isotopes in animals. Geochimica et cosmochimica acta, 42(5), 495-506.

DeNiro, M. J., \& Epstein, S. (1981). Influence of diet on the distribution of nitrogen isotopes in animals. Geochimica et cosmochimica acta, 45(3), 341-351.

Gould, S. J. (1966). Allometry and size in ontogeny and phylogeny. Biological Reviews, 41(4), 587-638.

Hatase, H., Takai, N., Matsuzawa, Y., Sakamoto, W., Omuta, K., Goto, K., Nobuaki, A., \& Fujiwara, T. (2002). Size-related differences in feeding habitat use of adult female loggerhead turtles Caretta caretta around Japan determined by stable isotope analyses and satellite telemetry. Marine Ecology Progress Series, 233, 273-281.

Hatase, H., Sato, K., Yamaguchi, M., Takahashi, K., \& Tsukamoto, K. (2006). Individual variation in feeding habitat use by adult female green sea turtles (Chelonia mydas): are they obligately neritic herbivores? Oecologia, 149(1), 52-64.

Hatase, H., Omuta, K., \& Komatsu, T. (2014). Do loggerhead turtle (Caretta caretta) eggs vary with alternative foraging tactics? Journal of experimental marine biology and ecology, 455, 56-61.

IUCN 2015. The IUCN Red List of Threatened Species. Version 2015-4. <http://www.iucnredlist.org >. Downloaded on 19 November 2015.

Lutz, P.L.; Musick, J.A. (1997). The biology of sea turtles. Boca Raton: CRC Press. 432 p.

Marques, T. S., Lara, N. R., Camargo, P. B., Verdade, L. M., \& Martinelli, L. A. (2014a). The Use of Stable Isotopes Analysis in Wildlife Studies. In Applied Ecology and Human Dimensions in Biological Conservation (pp. 159-174). Springer, Berlin, Heidelberg. 
Marques, T. S., Bassetti, L. A., Lara, N. R., Araújo, M. S., Piña, C. I., Camargo, P. B., \& Verdade, L. M. (2014b). Isotopic discrimination factors $(\Delta 13 \mathrm{C}$ and $\Delta 15 \mathrm{~N})$ between tissues and diet of the broad-snouted Caiman (Caiman latirostris). Journal of Herpetology, 48(3), 332-337.

MMA - Ministério do Meio Ambiente. (2014). Portaria No 444, 17/12/2014. Dispõe sobre as espécies da fauna brasileira ameaçadas de extinção. Pp. 121-126. In: Diário Oficial da União, Brasília, DF, nº 245 publicado em 18/12/2014, Seção 1.

Mohr, L. V., Castro, J. W. A., Costa, P. M. S., \& Alves, R. J. V. (2009). Ilhas Oceânicas brasileiras: da pesquisa ao manejo-volume II. Brasília: MMA/Secretaria de Biodiversidade e Florestas.

Pereira-Filho, G. H., Amado-Filho, G. M., Guimarães, S. M., Moura, R. L., Sumida, P. Y., Abrantes, D. P., ... \& Francini Filho, R. B. (2011). Reef fish and benthic assemblages of the Trindade and Martin Vaz island group, southwestern Atlantic. Brazilian Journal of Oceanography, 59(3), 201-212.

Peters, R. H. (1986). The ecological implications of body size (Vol. 2). Cambridge University Press.

Pinckney, J. (1990). Correlation analysis of adult female, egg and hatchling sizes in the loggerhead turtle, Caretta caretta (L.), nesting at Kiawah Island, South Carolina, USA. Bulletin of marine science, 47(3), 670-679.

Rosalino, L. M., Martin, P. S., Gheler-Costa, C., Lopes, P. C., \& Verdade, L. M. (2013). Allometric relations of Neotropical small rodents (Sigmodontinae) in anthropogenic environments. Zoological science, 30(7), 585-590.

Van Buskirk, J., \& Crowder, L. B. (1994). Life-history variation in marine turtles. Copeia, 66-81. Vander Zanden, H. B., Pfaller, J. B., Reich, K. J., Pajuelo, M., Bolten, A. B., Williams, K. L., ... \& Bjorndal, K. A. (2014). Foraging areas differentially affect reproductive output and interpretation of trends in abundance of loggerhead turtles. Marine biology, 161(3), 585-598.

Verdade, L. M. (2000). Regression equations between body and head measurements in the broadsnouted caiman (Caiman latirostris). Revista Brasileira de Biologia, 60(3), 469-482.

Verdade, L. M. (2001). Allometry of reproduction in broad-snouted caiman (Caiman latirostris). Brazilian Journal of Biology, 61(3), 431-435.

Wallace, B. P., Sotherland, P. R., Tomillo, P. S., Bouchard, S. S., Reina, R. D., Spotila, J. R., \& Paladino, F. V. (2006). Egg components, egg size, and hatchling size in leatherback turtles. Comparative Biochemistry and Physiology Part A: Molecular \& Integrative Physiology, 145(4), 524-532.

Warner, D. A., \& Lovern, M. B. (2014). The Maternal Environment Affects Offspring Viability via an Indirect Effect of Yolk Investment on Offspring Size. Physiological and Biochemical Zoology: Ecological and Evolutionary Approaches, 87(2), 276-287. http://doi.org/10.1086/674454. 
Zbinden, J. A., Bearhop, S., Bradshaw, P., Gill, B., Margaritoulis, D., Newton, J., \& Godley, B. J. (2011). Migratory dichotomy and associated phenotypic variation in marine turtles revealed by satellite tracking and stable isotope analysis. Marine Ecology Progress Series, 421, 291302. 


\section{Alometria reprodutiva: influência do tamanho corporal no investimento reprodutivo da tartaruga-verde Chelonia mydas na Ilha da Trindade, Atlântico ocidental, com subsídios para o monitoramento reprodutivo da espécie}

\section{Resumo}

Informações sobre as relações entre tamanho corporal de fêmeas e características que conferem maior fitness à sua reprodução (i.e., ninhadas com maior número de ovos e/ou ovos maiores) ajudam no entendimento sobre a história de vida das espécies e auxiliam em planos de sua conservação. Neste estudo, buscamos avaliar a relação do tamanho de fêmeas de tartaruga-verde (Chelonia mydas) com os parâmetros de reprodução citados e com a largura de rastros deixados na praia de nidificação. Coletamos os dados deste estudo na Ilha da Trindade, situada no oceano Atlântico e distante há $1140 \mathrm{~km}$ da costa brasileira. Coletamos dados biométricos das fêmeas (i.e., comprimento e largura curvilíneos da carapaça), medimos as larguras dos rastros deixados pelas fêmeas na areia da praia no momento da nidificação e coletamos dados de ninhada (i.e., tamanho da ninhada e massa e diâmetro dos ovos). Por meio de regressões lineares e quadráticas, avaliamos as relações do tamanho das fêmeas com a largura de seus rastros e os dados de suas ninhadas. Encontramos uma relação significativamente positiva do comprimento e da largura curvilíneos da carapaça com a largura dos rastros e com o tamanho das ninhadas e dos ovos. Concluímos que fêmeas maiores, principalmente no que se refere ao comprimento curvilíneo da carapaça, são as que mais contribuem para o sucesso reprodutivo da espécie.

\subsection{Introdução}

Estudos sobre alometria reprodutiva avaliam possíveis relações de tamanho do corpo da mãe com características relacionadas ao seu investimento reprodutivo (e.g., tamanho de ninhada e tamanho de ovos e filhotes) (e.g., Pinckney 1990). O investimento reprodutivo das fêmeas de tartarugas marinhas também ocorre em função do número de posturas realizadas em cada estação reprodutiva, do intervalo de remigração (intervalo de tempo entre as estações) e da longevidade reprodutiva das fêmeas adultas. Esses três parâmetros apresentam variações intraespecíficas; no entanto, são necessários estudos de longo prazo para sua determinação, sobretudo para os últimos e em áreas onde a população nidificante é grande. Há na literatura diversos trabalhos que envolvem alometria reprodutiva de quelônios utilizando como parâmetros tamanho da ninhada e tamanho dos ovos (e.g., Bonach et al. 2006; Cheng et a. 2009; Hatase et al. 2014;). A coleta desses dados é relativamente simples, uma vez que se tem acesso às fêmeas em áreas de nidificação.

$\mathrm{Na}$ areia das praias de nidificação, dependendo da área, é possível encontrar um grande número de rastros das fêmeas nidificantes. Esses rastros, no entanto, apresentam uma variação de tamanho, no que diz respeito à sua largura. É razoável supor que tal variação se deva à variação 
de tamanho entre as fêmeas responsáveis por esses rastros. As fêmeas de tartarugas marinhas apresentam uma ampla variação de tamanho corporal, mesmo entre as adultas de uma mesma área de nidificação (Cheng et al. 2009; Almeida et al. 2011; Chambault et al. 2016;). Para C. mydas, essa variação ultrapassa os $50 \mathrm{~cm}$ (Almeida et al. 2011) e, o tamanho da ninhada (i.e., número de ovos de um ninho), por sua vez, pode variar de 36 a 219 ovos (Bjorndal \& Carr 1989).

Ninhadas maiores e/ou com ovos maiores configuram maior fitness à prole da espécie. Quanto maior o número de ovos produzidos pela fêmea, maior é a probabilidade de um de seus descendentes alcançar a vida adulta. Até atingirem a idade reprodutiva, os ovos, filhotes e juvenis de tartarugas marinhas enfrentam um conjunto grande de ameaças, que vão desde o número naturalmente grande de predadores até fatores antropogênicos (Baptistotte 2007; Booth et al. 2013). Dessa forma, a produção de uma ninhada maior, que origine um maior número de descendentes, certamente configura uma vantagem reprodutiva bastante significativa. Além disso, ovos maiores geram filhotes maiores, que apresentam algum grau de vantagem sobre os filhotes menores em termos de fuga de predadores, seletividade de tamanho de predadores, já que predadores menores selecionam presas menores por questões anatômicas, e agilidade no alcance do mar e de áreas mais seguras dentro dele (Booth et. al. 2013).

Em relação às fêmeas de C. mydas, Bjorndal \& Carr (1989) verificaram que o tamanho corporal das fêmeas (i.e., comprimento e largura retilíneos da carapaça, comprimento do plastrão e massa corporal) está positivamente relacionado com o tamanho da sua ninhada e com o diâmetro de seus ovos. Esses resultados foram corroborados por Cheng et al. (2009). Bjorndal \& Carr (1989) ressaltam que o tamanho corporal da fêmea explica mais o tamanho da ninhada que o tamanho dos ovos.

Para maior entendimento sobre a ecologia reprodutiva de $C$. mydas e sobre a relação dos rastros das fêmeas com o tamanho de seu corpo, o presente estudo procurou esclarecer as possíveis relações entre a largura dos rastros e tamanho corporal das fêmeas e destes com seu investimento reprodutivo (i.e. número e tamanho de ovos por ninho).

\subsection{Metodologia}

\subsubsection{Metodologia amostral}

Realizamos a coleta de dados deste estudo entre fevereiro e abril de 2017. Nesses dois meses, monitoramos durante a noite/madrugada (entre $20 \mathrm{~h}$ e $6 \mathrm{~h}$ ) duas praias diferentes da Ilha da Trindade (Tartarugas e Andradas) de forma alternada. Dessa forma, cada noite monitorávamos uma praia. Iniciávamos o monitoramento caminhando pela praia até o encontro de uma fêmea em processo de nidificação. Quando verificávamos o início de sua postura, introduzíamos, dentro do ninho, uma pequena bola de isopor ligada a uma extremidade de uma vareta de PVC por meio de uma corda fina. Em seguida, fincávamos a vareta na areia, na posição vertical. Isso facilitava o 
encontro exato do ninho após a sua cobertura pela fêmea, quando ela finalizava sua postura (Figura 2.1).

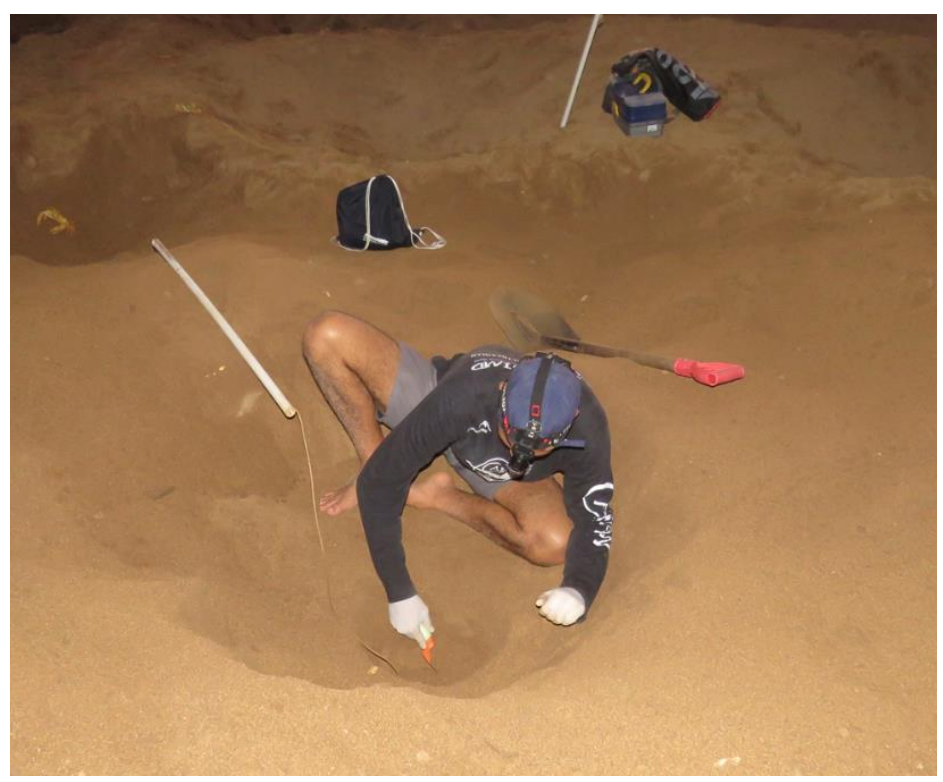

Figura 2.1 Ninho de C. mydas marcado com vareta de pvc. Ao fundo da imagem é possível observar uma vareta na vertical, com o ninho fechado. À frente, durante o processo de abertura do ninho, a pequena bola de isopor permanece dentro dele, ligada à vareta através da corda.

Para a coleta dos dados, esperávamos a finalização da desova de cada fêmea, buscando minimizar o estresse e evitar a influência desse fator na postura. Somente após a cobertura de seus ninhos dávamos início à biometria das fêmeas. Com uma fita métrica, medíamos o comprimento curvilíneo da carapaça (CCC) e a largura curvilínea da carapaça (LCC). Com o auxílio de uma pá, cavávamos a areia e abríamos seus ninhos para registrarmos o tamanho da ninhada (i.e., quantidade de ovos no ninho). Em seguida, espanávamos os ovos com um pano seco para retirarmos a areia aderida a eles e evitarmos, assim, sua influência nas medidas. Os ovos das tartarugas marinhas são depositados em seus ninhos envoltos por um fluido cloacal. Apesar de sua função exata ainda não ser determinada (Keene et al. 2014), alguns estudos sugerem seu efeito anti-microbiano (Soslau et al. 2011). Por isso, de forma a minimizar o impacto do nosso estudo no desenvolvimento dos ovos, fizemos uma amostragem do ninho (i.e., retirada da areia, pesagem e medição dos ovos) de acordo com os seguintes critérios: i) ninhos contendo até 100 ovos: amostra de 50 ovos; ii) ninhos com mais de 100 ovos: amostras de $50 \%$ do total. Prosseguíamos, então, verificando a massa e o diâmetro dos ovos em uma balança digital e um paquímetro de 0,1 g e 0,02 mm de precisão, respectivamente. Após poucas horas da ovoposição pela fêmea no ninho, o ovo recomeça seu desenvolvimento e se for movimentado após esse período é levado à morte (Limpus et al. 1979; Parmenter 1980). Para agilizarmos esse processo, as medidas dos diâmetros foram registradas com precisão de $0,5 \mathrm{~mm}$. Por fim, devolvíamos os ovos aos seus ninhos e fechávamos com a areia retirada. 
Para verificarmos a relação das medidas dos rastros com as medidas das fêmeas, fizemos uma coleta à parte. Estabelecemos rastros marcados apenas na faixa de areia mais próxima ao mar, onde a areia se encontrava molhada, pois os rastros eram mais bem delimitados. Medíamos os rastros apenas após a finalização da postura dos ovos pelas tartarugas, quando elas estavam retornando ao mar, para não estressá-las e evitarmos que abandonassem a postura. Nesse momento fazíamos sua biometria (CCC e LCC). Para mensuração da largura do rastro, identificávamos seu trecho mais retilíneo possível e, com uma trena métrica, medíamos a maior largura marcada pelas nadadeiras anteriores (Figura 2.2).

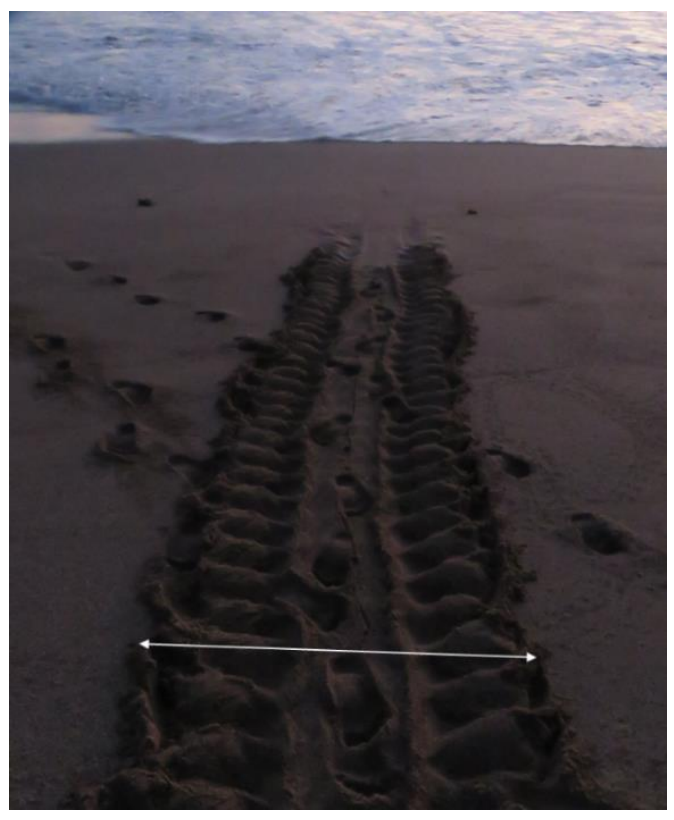

Figura 2.2. Rastro de C. mydas marcado em areia úmida. As pontas das setas indicam as extremidades da largura do rastro.

\subsubsection{Metodologia analítica}

Foram feitas as seguintes análises de regressão, por meio do software Minitab17:

Tabela 2.1 Equação de regressão linear relacionando tamanho da fêmea com a largura de seus rastros e com o tamanho de sua ninhada. CCC - comprimento curvilíneo da carapaça e LCC largura curvilínea da carapaça

\begin{tabular}{cc}
\hline $\mathbf{Y}(\mathbf{c m})$ & $\mathbf{X}$ \\
\hline CCC & Largura do rastro (cm) \\
CCC & Tamanho da ninhada (número de ovos) \\
CCC & Diâmetro dos ovos (cm) \\
CCC & Massa dos ovos $(\mathrm{g})$ \\
LCC & Largura do rastro (cm) \\
LCC & Tamanho da ninhada (número de ovos) \\
LCC & Diâmetro dos ovos (cm) \\
LCC & Massa dos ovos (g) \\
\hline
\end{tabular}




\subsection{Resultados}

Neste estudo registramos rastros entre 93,5 e $125 \mathrm{~cm}$ de largura, referentes a 31 fêmeas de tartaruga-verde em nidificação entre 89 e $123 \mathrm{~cm}$ de CCC e entre 88 e $111 \mathrm{~cm}$ de LCC. É possível estimar CCC e LCC das fêmeas de C. mydas a partir da largura de seus rastros (Figura 2.3).

Registramos 38 fêmeas em processo de desova com CCC entre 89 e 124,5 cm e LCC entre 88 e $111 \mathrm{~cm}$, cujos ninhos continham de 58 a 165 ovos. O tamanho da ninhada é diretamente proporcional ao tamanho da fêmea (CCC e LCC). É possível estimar o tamanho da ninhada a partir dessas medidas (Figura 2.4).

Fizemos a pesagem e a medição de 2276 ovos, referentes a 38 fêmeas. O diâmetro e a massa dos ovos são diretamente proporcionais ao tamanho da fêmea (Figuras 2.5 e 2.6). 


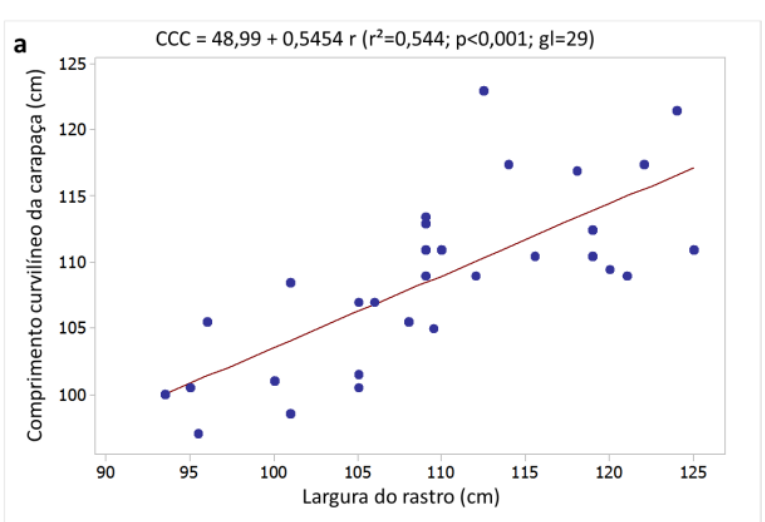

Figura 2.3 Relação entre largura do rastro (r) e (a) comprimento curvilíneo da carapaça (CCC) e (b) largura curvilínea da carapaça (LCC). As equações nos gráficos são referentes a

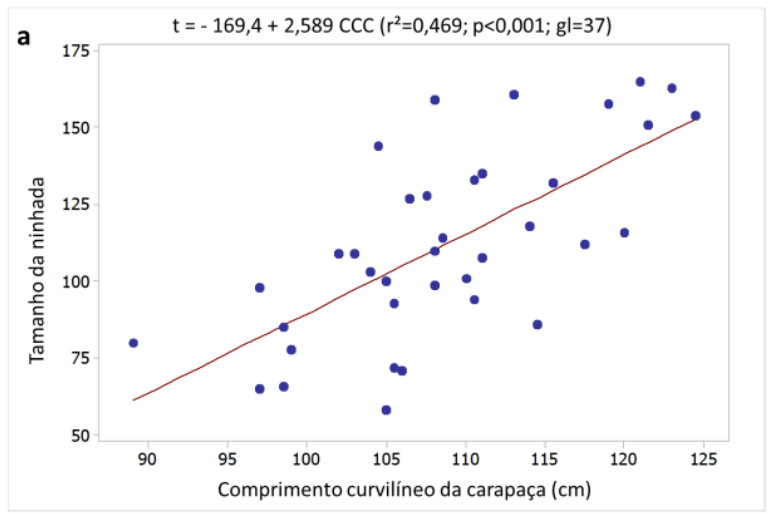

Figura 2.4 Relação entre tamanho da ninhada (t) e (a) comprimento curvilíneo da carapaça (CCC) e (b) largura curvilínea da carapaça (LCC). As equações nos gráficos são

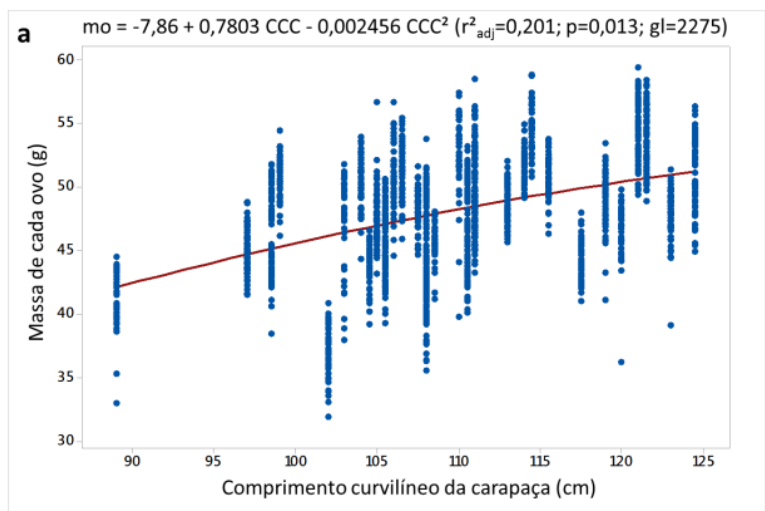

Figura 2.5 Relação entre massa dos ovos (mo) e (a) comprimento curvilíneo da carapaça (CCC) e (b) largura curvilínea da carapaça (LCC). As equações nos gráficos são

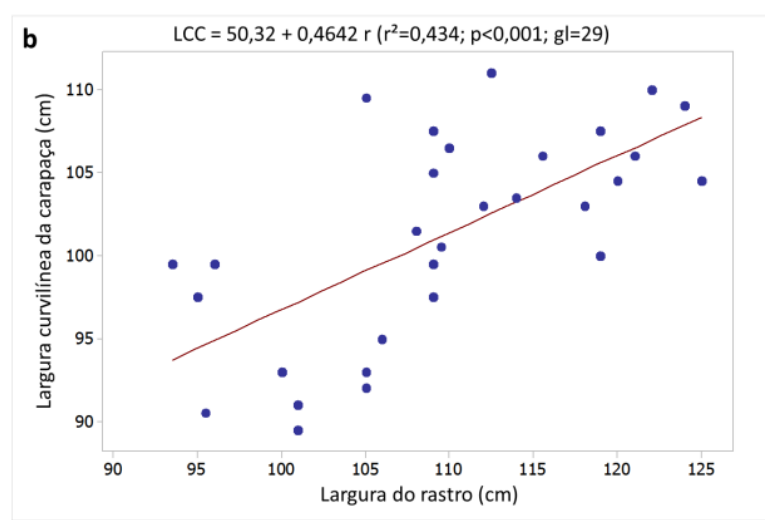

cada relação. $r^{2}$ : coeficiente de determinação da regressão linear, $p$ : p-valor, $g l$ : graus de liberdade.

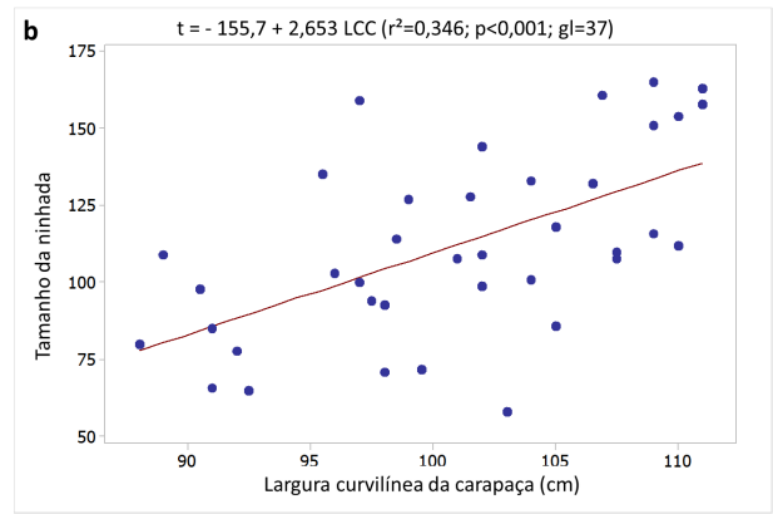

referentes a cada relação. $r^{2}$ : coeficiente de determinação da regressão linear, $p$ : p-valor, $g l$ : graus de liberdade.

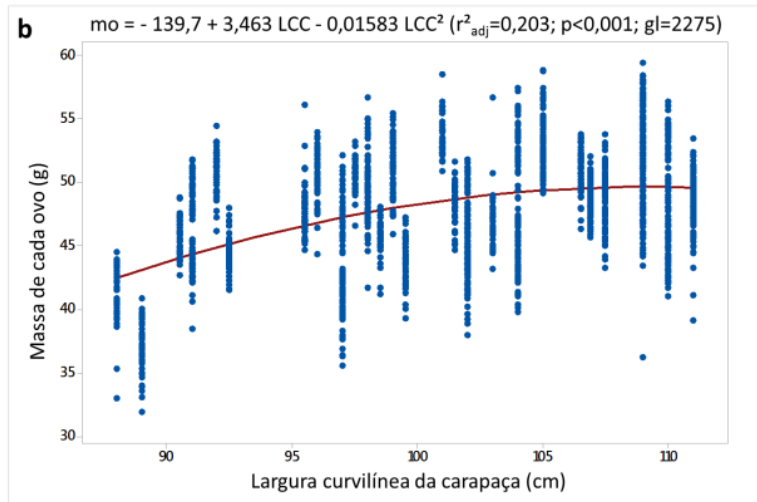

referentes a cada relação. $r^{2}$ : coeficiente de determinação da regressão quadrática, $p$ : p-valor, $g l$ : graus de liberdade. 


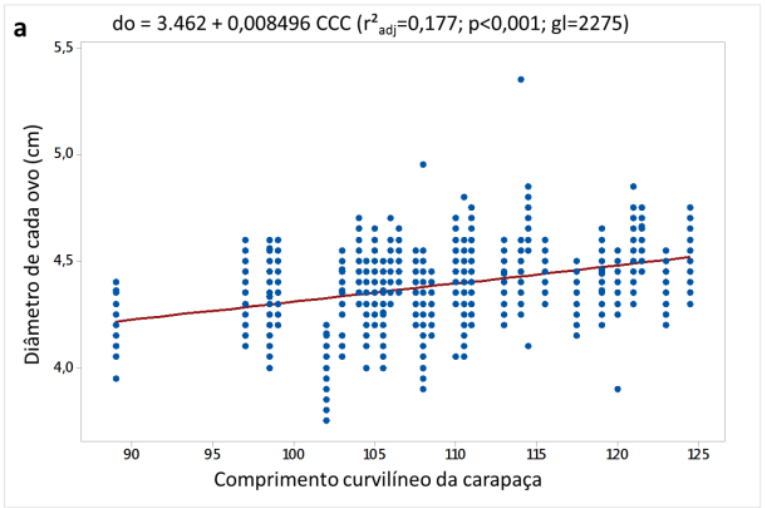

Figura 2.6 Relação entre diâmetro dos ovos (do) e (a) comprimento curvilíneo da carapaça (CCC) e (b) largura curvilínea da carapaça (LCC). As equações nos gráficos são

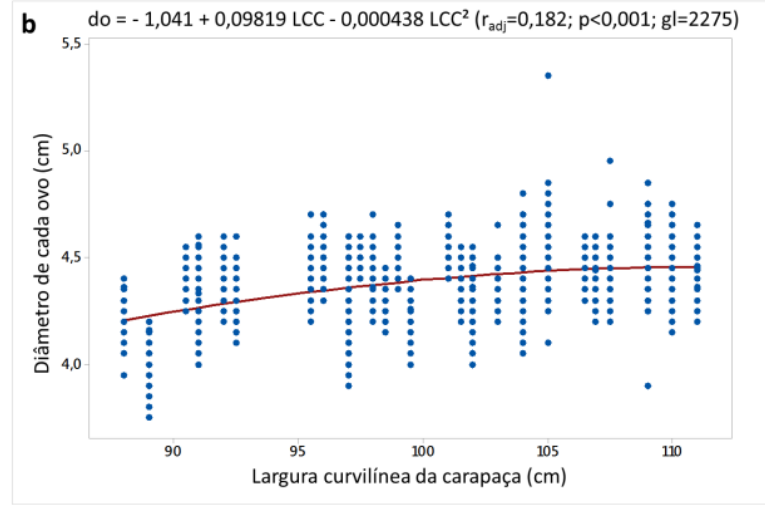

referentes a cada relação. $r^{2}$ : coeficiente de determinação da regressão linear ou quadrática, $p$ : $\mathrm{p}$-valor, $g l$ : graus de liberdade. 


\subsection{Discussão}

Não encontramos estudos prévios que tenham avaliado a relação entre o comprimento e a largura da carapaça de tartarugas marinhas e seus rastros, o que não deixa de ser surpreendente, já que essas medidas são facilmente obtidas em praias de desova. De qualquer forma, a padronização da medida da largura do rastro é, obviamente, importante para usa-la de forma segura para se entender melhor os processos e as relações que as envolvem. Bonach et al. (2006), usaram a largura do rastro do plastrão e das nadadeiras posteriores de tartaruga-da-amazônia (Podocnemis expansa) como estimativa de tamanho da fêmea, assumindo que fêmeas maiores deixavam rastros maiores, o que é confirmado em nosso estudo com tartaruga-verde para o ambiente marinho. Encontramos forte relação entre a largura do rastro e o comprimento curvilíneo da carapaça $\left(r^{2}=0,544\right.$, Figura 2.3a). Possivelmente uma das formas mais baratas de monitoramento em praias de nidificação, a medição da largura dos rastros pode fornecer informações importantes na avaliação das tendências populacionais.

A relação positiva forte encontrada entre o tamanho da fêmea (CCC e LCC) e o tamanho de sua ninhada corroboram outros estudos que avaliaram essa mesma relação entre fêmeas de quelônios e crocodilianos e suas ninhadas (C. mydas, Bjorndal et al. 1989; C. caretta, Pinckney 1990; C. caretta e C. mydas, Broderick et al. 2003; Caiman latirostris, Larriera et al. 2004; P. espansa, Bonach et al. 2006; C. mydas, Cheng et al. 2009), que pode ser explicada pela maior cavidade do corpo das tartarugas maiores, além de possíveis variações na qualidade da alimentação das mesmas (Shine 1988; Broderick et. al. 2003; Hatase et. al. 2013).

A relação positiva entre o tamanho da fêmea e o tamanho de seus ovos também corrobora resultados obtidos em outros trabalhos com tartarugas e jacarés (C. mydas, Bjorndal e Carr 1989; C. caretta, Pinckey 1990; C. mydas, Hays et al. 1993; C. latirostris, Verdade et al. 2001). Broderick et al. (2003) não encontraram relação entre o tamanho da fêmea e o tamanho do ovo (diâmetro e massa do ovo). No entanto, o tamanho das amostras para essa avaliação foi relativamente pequenas $(\mathrm{n}=20$ ninhadas de $C$. caretta e $\mathrm{n}=11$ ninhadas de $C$. mydas). Os próprios autores não excluem o tamanho do ovo como uma variável importante no investimento reprodutivo dessas espécies, considerando o resultado de sua avaliação contrastante com outros estudos (e.g., Bjorndal \& Carr 1989; Hays et al. 1993).

Os coeficientes de determinação das relações entre tamanho da fêmea e tamanho da ninhada $\left(r^{2}=0,469\right.$ e $r^{2}=0,346$; CCC e LCC, respectivamente) são expressivamente maiores que os coeficientes das relações entre tamanho da fêmea e tamanho dos ovos, onde o maior coeficiente está na relação entre massa de cada ovo e largura da carapaça $\left(r^{2}=0,203\right)$. Talvez, para a reprodução, seja mais vantajoso à fêmea investir mais na quantidade de ovos do que no seu tamanho. Janzen (1993) e Congdon et al. (1999) testaram a hipótese "maior é melhor" com filhotes de tartaruga de água doce Chelydra serpentina e obtiveram resultados divergentes. Booth 
et al. (2013) verificaram que a massa dos ovos de C. mydas influencia na massa e no comprimento da carapaça de seus filhotes, mas características atribuídas ao seu desempenho (e.g., impulso de nado durante os primeiros 30 minutos) são mais influenciadas pela temperatura da incubação dos ovos. Ainda que filhotes maiores tenham maior chance de escapar de predadores menores (por limitações anatômicas), é possível que, para C. mydas, a maior probabilidade de sobrevivência de filhotes maiores em relação a filhotes menores não seja tão expressiva. Ao passo que a probabilidade de algum filhote chegar à idade adulta, provavelmente aumenta em ninhos maiores.

Uma informação que deve ser considerada a respeito da metodologia do presente estudo é que foram contados e medidos os ovos de apenas um ninho de cada fêmea. O número de posturas por fêmea numa temporada reprodutiva pode variar entre as áreas de nidificação (e consequentemente entre as diferentes populações) assim como entre as temporadas (Carr et. al. 1978, Bjorndal et. al. 1999). De qualquer forma, em geral, as fêmeas realizam mais de uma postura por temporada. Assim, é provável que estejam sendo comparadas as ninhadas de fêmeas em estágios diferentes da temporada, ou seja, algumas numa fase mais inicial e outras numa fase mais avançada da temporada reprodutiva. Com exceção de um indivíduo, não foi possível coletar os dados de mais de um ninho da mesma fêmea, devido aos seguintes fatores: $i$ ) grande número de fêmeas nas praias, $i i$ ) dificuldade logística em se monitorar as duas praias ao mesmo tempo e iii) preocupação em causar o menor estresse possível às fêmeas (elas eram identificadas somente após a finalização do processo de desova). No caso em que isso foi possível, as duas posturas ocorreram num intervalo de 15 dias, sendo o primeiro ninho com 109 e o segundo com 116 ovos. Bjorndal e Carr (1989) não encontraram diferenças significativas, em nível de indivíduo, entre o número de ovos das diferentes posturas de C. mydas numa mesma temporada reprodutiva em Tortuguero, na Costa Rica. Já Broderick et al. (2003) verificaram no Norte do Chipre um aumento gradual no tamanho da ninhada da mesma espécie à medida que a estação reprodutiva avançava, atingindo o maior número de ovos por ninhada na terceira ou quarta postura.

Além do tamanho da ninhada e do tamanho dos ovos, o investimento reprodutivo em tartarugas marinhas é também uma função do número de posturas numa temporada reprodutiva, dos intervalos entre temporadas reprodutivas e do tempo de vida reprodutiva de cada tartaruga (Bjorndal \& Carr 1989). Essas informações não foram avaliadas no presente trabalho, e nem seria possível obtê-las num estudo como esse. No entanto, Broderick et. al. (2003) verificaram que tartarugas maiores não realizam mais posturas que tartarugas menores. Também, de acordo com esses autores, as fêmeas tendem a colocar ninhadas maiores numa temporada reprodutiva subsequente à anterior. Nesse caso, o aumento da ninhada não se deu pelo aumento de tamanho da fêmea, uma vez que a taxa de crescimento durante o estudo foi insignificante, mas sim por fatores ambientais (e.g., disponibilidade e/ou qualidade do alimento).

Com este estudo vimos que fêmeas maiores deixam rastros mais largos e produzem ninhadas maiores com ovos também maiores. Como não foi possível determinarmos a idade das 
fêmeas, não sabemos, no entanto, se esta característica também está associada a alguma mudança ontogenética na estratégia reprodutiva da espécie. Com as equações fornecidas aqui, a partir da medida da largura do rastro, é possível mensurar o comprimento e a largura curvilíneos da carapaça da fêmea. Com essa medida, é possível estimar o tamanho de sua ninhada. Como o coeficiente de determinação é maior na equação da relação do tamanho da ninhada com CCC do que com LCC, recomendamos o uso da primeira medida para estimativa de tamanho de ninhada. Para as praias de nidificação da espécie onde já ocorre monitoramento das fêmeas, é possível agora aprimorar as avaliações de tendências populacionais introduzindo estimativas de tamanhos de ninhadas sem, no entanto, a necessidade da abertura dos ninhos.

No Brasil, as três principais áreas de nidificação da espécie são Ilha da Trindade, seguida por Atol das Rocas e Fernando de Noronha. Segundo Almeida et al. (2011), a população de fêmeas que nidificam na Ilha da Trindade se diferencia geneticamente da população das outras duas áreas, que não diferem entre si. A verificação dessas relações nas outras áreas poderá fornecer equações ajustadas a elas. Assim, será possível uma avaliação mais segura de tendências populacionais da espécie em nível nacional.

Nas duas praias da Ilha da Trindade encontramos inúmeros filhotes mortos sem qualquer marca de predação. Os filhotes, quando permanecem nas praias por longos períodos, principalmente durante o dia, podem morrer por dessecação, superaquecimento por exposição ao sol e predação (Steyemark \& Spotila 2001). Sugerimos, como estudos futuros, a verificação da relação do tamanho dos filhotes mortos na areia (possivelmente devido à exposição a altas temperaturas durante o dia) com as classes de tamanho de filhotes que nascem na ilha. Dessa forma, pode-se esclarecer a relação do tamanho dos filhotes com a agilidade na areia após emergirem dos ninhos, visto que os mais lentos ficarão expostos às condições adversas por mais tempo antes de alcançarem o mar. Informações como essa auxiliam no maior entendimento sobre a história natural e características evolutivas e ecológicas da espécie.

\subsection{Conclusão}

A forte relação entre o tamanho da fêmea (i.e., CCC) e a largura de seu rastro indica a última medida como dado importante no monitoramento em praias de nidificação. Verificamos um perfil de tamanho de fêmea de C. mydas, em relação ao comprimento e à largura curvilíneos da carapaça, que mais contribui para a reprodução da espécie: tartarugas maiores tendem a produzir ovos maiores e em maior quantidade. Essa informação contribui não só com o conhecimento sobre a história de vida da espécie, mas também com planos de conservação. Além das praias de nidificação, esses planos devem considerar também os locais onde a espécie vive quando não está em fase de reprodução, ou seja, suas áreas de alimentação. Para isso, recomendamos estudos que esclareçam a relação dessas áreas com o tamanho das fêmeas. Estudos que envolvam telemetria por satélite e análise de isótopos estáveis em fêmeas nidificantes, podem 
auxiliar. Além disso, uma possível compilação de dados biométricos do projeto TAMAR/ICMBio ao longo da costa brasileira poderia auxiliar na identificação dos locais onde as fêmeas maiores nidificam e onde os maiores indivíduos se alimentam. Tais áreas devem ser consideradas como prioritárias nos planos para o estabelecimento de áreas protegidas.

\section{Referências bibliográficas}

Almeida, A.P., Moreira, L.M.P., Bruno S.C., Thomé, J.C.A., Martins, A.S., Bolten, A.B., Bjorndal, K.A. (2011) Green turtle nesting on Trindade Island, Brazil: abundance, trends, and biometrics. Endang Species Res 14:193-201.

Baptistotte, C. (2007). Caracterização espacial e temporal da fibropapilomatose em tartarugas marinhas da costa brasileira (Doctoral dissertation, Universidade de São Paulo).

Bjorndal, K. A., \& Carr, A. (1989). Variation in clutch size and egg size in the green turtle nesting population at Tortuguero, Costa Rica. Herpetologica, 181-189.

Bjorndal, K. A., Wetherall, J. A., Bolten, A. B., \& Mortimer, J. A. (1999). Twenty-Six Years of Green Turtle Nesting at Tortuguero, Costa Rica: An Encouraging Trend. Conservation Biology, 13(1), 126-134.

Bonach, K., Piña, C. I., \& Verdade, L. M. (2006). Allometry of reproduction of Podocnemis expansa in Southern Amazon basin. Amphibia-Reptilia, 27(1), 55-61

Booth, D. T., Feeney, R., \& Shibata, Y. (2013). Nest and maternal origin can influence morphology and locomotor performance of hatchling green turtles (Chelonia mydas) incubated in field nests. Marine Biology, 160(1), 127-137.

Broderick, A. C., Glen, F., Godley, B. J., \& Hays, G. C. (2003). Variation in reproductive output of marine turtles. Journal of Experimental Marine Biology and Ecology, 288(1), 95-109.

Carr, A. F., Carr, M. H., \& Meylan, A. B. (1978). The ecology and migrations of sea turtles. 7 , The West Caribbean green turtle colony. Bulletin of the AMNH; v. 162, article 1.

Cheng, I. J., Huang, C. T., Hung, P. Y., Ke, B. Z., Kuo, C. W., \& Fong, C. L. (2009). Ten years of monitoring the nesting ecology of the green turtle, Chelonia mydas, on Lanyu (Orchid Island), Taiwan. Zoological Studies, 48(1), 83-94.

Chambault, P., De Thoisy, B., Kelle, L., Berzins, R., Bonola, M., Delvaux, H., ... \& Chevallier, D. (2016). Inter-nesting behavioural adjustments of green turtles to an estuarine habitat in French Guiana. Marine Ecology Progress Series, 555, 235-248.

Congdon, J. D., Nagle, R. D., Dunham, A. E., Beck, C. W., Kinney, O. M., \& Yeomans, S. R. (1999). The relationship of body size to survivorship of hatchling snapping turtles (Chelydra serpentina): an evaluation of the "bigger is better" hypothesis. Oecologia, 121(2), 224-235.

Hatase, H., Omuta, K., \& Tsukamoto, K. (2013). A mechanism that maintains alternative life histories in a loggerhead sea turtle population. Ecology, 94(11), 2583-2594. 
Hatase, H., Omuta, K., \& Komatsu, T. (2014). Do loggerhead turtle (Caretta caretta) eggs vary with alternative foraging tactics?. Journal of Experimental Marine Biology and Ecology, 455, 56-61.

Hays, G. C., Adams, C. R., \& Speakman, J. R. (1993). Reproductive investment by green turtles nesting on Ascension Island. Canadian Journal of Zoology, 71(6), 1098-1103.

Janzen, F. J. (1993). An experimental analysis of natural selection on body size of hatchling turtles. Ecology, 74(2), 332-341.

Keene, E., Soule, T., \& Paladino, F. (2014). Microbial Isolations from Olive Ridley (Lepidochelys olivacea) and East Pacific Green (Chelonia mydas agassizii) Sea Turtle Nests in Pacific Costa Rica, and Testing of Cloacal Fluid Antimicrobial Properties. Chelonian Conservation and Biology, 13(1), 49-55.

Larriera, A., Piña, C. I., Siroski, P., \& Verdade, L. M. (2004). Allometry of reproduction in wild broad-snouted caimans (Caiman latirostris). Journal of Herpetology, 38(2), 301-304.

Limpus, C. J., Baker, V., \& Miller, J. D. (1979). Movement induced mortality of loggerhead eggs. Herpetologica, 335-338.

Parmenter, C. J. (1980). Incubation of the eggs of the green sea turtle, Chelonia mydas, in Torres Strait, Australia: the effect of movement on hatchability. Wildlife Research, 7(3), 487-491.

Pinckney, J. (1990). Correlations analysis of adult female, egg and hatchlings sizes in the loggerhead turtle, Caretta Caretta (L.), nesting at Kiawah Island, South Carolina, USA. Bulletin of Marine Science, 47 (3), 670-679.

Shine, R. (1988). The evolution of large body size in females: a critique of Darwin's" fecundity advantage" model. The American Naturalist, 131(1), 124-131.

Soslau, G., Spotila, J. R., Chun, A., Yi, S., \& Weber, K. T. (2011). Potentially lethal bacteria in leatherback turtle eggs in the wild threaten both turtles and conservationists. Journal of experimental marine biology and ecology, 410, 101-106.

Steyermark, A. C., \& Spotila, J. R. (2001). Effects of maternal identity and incubation temperature on hatching and hatchling morphology in snapping turtles, Chelydra serpentina. Copeia, 2001(1), 129-135.

Verdade, L. M. (2001). Allometry of reproduction in broad-snouted caiman (Caiman latirostris). Brazilian Journal of Biology, 61(3), 431-435. 


\section{Alometria isotópica: influência da dieta no tamanho corporal e no investimento reprodutivo da tartaruga-verde Chelonia mydas na Ilha da Trindade, Atlântico ocidental.}

\section{Resumo}

Informações sobre tamanho corporal e nível trófico de fêmeas de tartarugas marinhas auxiliam no entendimento de como ocorre o investimento reprodutivo das espécies, ajudam no entendimento de sua história natural e contribuem com planos relativos à sua conservação. Neste estudo, buscamos esclarecer a relação entre comprimento e largura curvilíneos da carapaça e dieta de fêmeas de tartaruga-verde (Chelonia mydas) com seu investimento reprodutivo (i.e., tamanho de ninhada) a fim de buscar o perfil de fêmea que mais contribui com a atividade reprodutiva. A Ilha da Trindade, localizada no oceano Atlântico, há quase $1140 \mathrm{~km}$ da costa brasileira, abriga a maior população de fêmeas em nidificação do país. Coletamos dados biométricos e diferentes tecidos de 40 fêmeas para análise de isótopos estáveis de ${ }^{15} \mathrm{~N}$ e ${ }^{13} \mathrm{C}$ para comparação de níveis tróficos e origem do carbono entre elas e determinamos o tamanho da ninhada de cada uma. Realizamos regressões lineares e quadráticas entre os valores de $\delta^{15} \mathrm{~N}$ e $\delta^{13} \mathrm{C}$ e as variáveis de tamanho corporal e tamanho da ninhada. Verificamos que $\delta^{15} \mathrm{~N}$ está positivamente relacionado com o tamanho corporal da fêmea (i.e., CCC, a LCC) e o tamanho da ninhada. No entanto, para $\delta^{13} \mathrm{C}$, entre as 36 relações testadas (isótopo vs variáveis) apenas quatro foram significativas com baixos coeficientes de determinação. Concluímos que fêmeas maiores e de níveis tróficos mais elevados, que incluem matéria animal em sua dieta, produzem mais ovos e contribuem mais para o sucesso reprodutivo da espécie.

\subsection{Introdução}

Estudos que avaliam a forma de investimento reprodutivo das espécies, sobretudo daquelas que se encontram ameaçadas, são fundamentais ao entendimento de sua história natural e ecologia populacional (Broderick et al. 2003) e também para a elaboração de planos para sua conservação. A forma com que uma fêmea investe na sua reprodução pode ser influenciada, entre outros fatores, por seu tamanho corpóreo (Viera et al. 2014) e pela variação na sua dieta (Broderick et al. 2003). A posição que ela ocupa na cadeia trófica pode fornecer informações úteis a esse respeito.

A tartaruga-verde, Chelonia mydas, vive seus primeiros anos de vida em ambiente pelágico, alimentando-se principalmente de animais planctônicos (Bjorndal 1997). Após esse primeiro estágio, movem-se para habitats neríticos, onde mudam sua dieta para onívora e, com o tempo, basicamente herbívora (Bjorndal \& Carr 1989). No entanto, alguns estudos com fêmeas em nidificação têm mostrado que indivíduos adultos podem incluir itens de fonte animal em sua dieta (Hatase et al. 2006; Shimada et al. 2014). A variação intraespecífica na dieta das espécies pode apresentar influência direta em diversos de seus aspectos ecológicos. 
Nas ilhas de Cabo Verde, no leste do Atlântico Norte, a 500 km da costa de Senegal, as fêmeas reprodutivas maiores de tartaruga-cabeçuda (Caretta caretta) apresentaram índice bioquímico (i.e., proporção RNA/DNA) mais elevado do que as fêmeas menores (Vieira et al. 2014). Esse índice aumenta conforme demanda celular por síntese proteica e crescimento. Além disso, os filhotes das fêmeas maiores também tendem a ser maiores. Tais autores sugerem que fêmeas grandes tenham maior potencial de crescimento devido a diferenças em suas dietas. Hatase et al. (2013) verificaram que fêmeas de tartaruga-cabeçuda que se alimentavam de animais bentônicos em áreas neríticas eram maiores e produziam mais ovos que aquelas que se alimentavam do macroplâncton em ambiente oceânico. Enquanto permanecem em seus habitats de forrageamento, as fêmeas de tartarugas marinhas acumulam a energia necessária para sua reprodução ao longo de vários anos (Vieira et. al. 2014). A nidificação das fêmeas pode ocorrer em intervalos de 2 a 3 anos (Bjornadal \& Carr 1989), o que pode variar em função da disponibilidade temporal e espacial de alimento.

Diversas abordagens são utilizadas para estudos sobre hábitos alimentares de tartarugas marinhas utilizando técnicas de lavagem esofágica (Santos et al. 2015), conteúdo estomacal (Parker et al. 2011, Carman et al. 2014, Santos et al. 2015), conteúdo intestinal (Parker et al. 2011), análise de fezes (Seminoff et al. 2002) e observação direta (Nagaoka et al. 2012). No entanto, muitas vezes, essas abordagens podem ser limitadas ao considerarem que os itens encontrados representam a dieta de longo prazo da espécie (Araújo et al. 2007). Os itens alimentares podem variar sazonal e espacialmente e o órgão analisado pode conter apenas alguns itens de cada vez (Araújo et al. 2007). Isso pode gerar superestimativas da especialização individual, informação restrita a dados recentes da dieta e desconsideração de itens que já foram digeridos quando se analisa, por exemplo, conteúdo intestinal. A análise de isótopos estáveis (AIE) em estudos de ecologia trófica é uma alternativa a essas outras abordagens e se baseia no fato de que a dieta consumida pelos animais é incorporada em seus tecidos. Como cada tecido apresenta um tempo de renovação (turnover) distinto, a AIE de diferentes tecidos, pode fornecer informações temporais diferente sobre a dieta. Através do metabolismo animal, os isótopos de ${ }^{15} \mathrm{~N}$ e ${ }^{13} \mathrm{C}$ da dieta são transferidos aos seus tecidos. Essa transferência inclui processos bioquímicos que podem enriquecer ou diminuir esses isótopos, comparados à dieta (Post 2002). Em geral, há um pequeno enriquecimento $(0,5-1 \%)$ de ${ }^{13} \mathrm{C}$ no animal em relação à sua dieta, chamado "fator de enriquecimento trófico" (TEF, sigla em inglês). Para o ${ }^{15} \mathrm{~N}$, esse enriquecimento ocorre em torno de 3,4\% de um nível trófico para o outro, apresentando grande importância em estudos de ecologia trófica (DeNiro \& Epstein 1981; Post 2002). No entanto, esse valor pode variar bastante entre as espécies.

Objetivamos, neste estudo, esclarecer a possível relação do tipo de dieta de fêmeas nidificantes de C. mydas com características de tamanho corporal e investimento reprodutivo, utilizando análise de isótopos estáveis. Neste estudo buscamos também fornecer algumas 
equações para conversão de valores de $\delta^{15} \mathrm{~N}$ e de $\delta^{13} \mathrm{C}$ entre diferentes tecidos, considerando que estudos com tartarugas marinhas, que utilizam a AIE, ainda carecem de protocolos e que a falta de padronização na escolha dos tecidos dificulta comparações e meta-análises (Ceriani et al., 2014).

\subsection{Metodologia}

\subsubsection{Metodologia amostral}

Realizamos a coleta de dados deste estudo entre fevereiro e abril de 2017. Nesses dois meses, monitoramos durante a noite/madrugada (entre 20h e $6 \mathrm{~h}$ ) duas praias diferentes da Ilha da Trindade (Tartarugas e Andradas) de forma alternada. Dessa forma, cada noite monitorávamos uma praia. Iniciávamos o monitoramento caminhando pela praia até o encontro de uma fêmea em processo de nidificação. Quando verificávamos o início de sua postura, introduzíamos, dentro do ninho, uma pequena bola de isopor ligada a uma extremidade de uma vareta de PVC por meio de uma corda fina. Em seguida, fincávamos a vareta na areia, na posição vertical. Isso facilitava o encontro exato do ninho após a sua cobertura pela fêmea, quando ela finalizava sua postura.

Para coleta dos dados, esperávamos a finalização da desova de cada fêmea, buscando minimizar o estresse e evitar a influência desse fator na postura. Somente após a cobertura de seus ninhos dávamos início à biometria das fêmeas. Com uma fita métrica, medíamos o comprimento curvilíneo da carapaça (CCC) e a largura curvilínea da carapaça (LCC).

Para a análise de isótopos estáveis, realizamos a coleta de amostras dos seguintes tecidos de cada fêmea: epiderme, sangue, queratina da carapaça, queratina da nadadeira e unha. Foram escolhidos alguns tecidos diferentes com a intenção de obtermos uma informação temporal ampla a respeito da dieta dos indivíduos. Foram coletados $11 \mathrm{ml}$ de sangue através do seio cervical lateral com agulha 40 x 1,20 mm acoplada à seringa de $10 \mathrm{ml}$ (ultrapassamos a marca dos $10 \mathrm{ml}$ da seringa e coletamos $11 \mathrm{ml}$ ). A região da pele onde foi introduzida a agulha foi previamente assepsiada com álcool iodado. Parte do sangue $(2 \mathrm{ml})$ foi transferida para um tubo com anticoagulante EDTA (para amostras de sangue total) e a outra parte $(9 \mathrm{ml})$ para um tubo com heparina sódica (para amostras de células vermelhas e plasma). Em seguida os tubos foram colocados em bolsas térmicas com gelo artificial para manterem-se resfriados em campo. Utilizamos os anticoagulantes de acordo com as recomendações de Lemons et al. (2012). A epiderme foi coletada no ombro direito, entre o pescoço e a nadadeira anterior, utilizando um punch de $6 \mathrm{~mm}$ descartável ou um bisturi estéril. A queratina da carapaça foi coletada em três regiões da segunda placa lateral direita: região anterior (tecido mais novo), região central e região posterior (tecido mais antigo) (adaptado de Reich et al. 2007, Figura 3.1). Para amostras da queratina da nadadeira, definimos a segunda escama da nadadeira direita e coletamos uma pequena amostra (aproximadamente $1 \mathrm{~cm}^{2}$ ) com um bisturi estéril. Coletamos uma pequena amostra (até $3 \mathrm{~mm}$ ) da região distal da unha da nadadeira direita com uma turquesa (um tipo de 
alicate). Com exceção do sangue, a região de coleta de todos os tecidos foi previamente assepsiada com álcool $70 \%$ e as amostras foram acondicionadas em eppendorfs separados para posterior processamento. A epiderme era mantida resfriada, em campo, juntamente com os tubos de sangue. Após a coleta dos tecidos da fêmea foram registrados dados referentes ao seu ninho. Com o auxílio de uma pá, cavávamos a areia e abríamos seus ninhos para registrarmos o tamanho da ninhada (i.e., quantidade de ovos no ninho) e para coletarmos um ovo de cada fêmea. A análise isotópica de um ovo por ninho se mostrou representativa em outros estudos (e.g., Hatase et al. 2002).

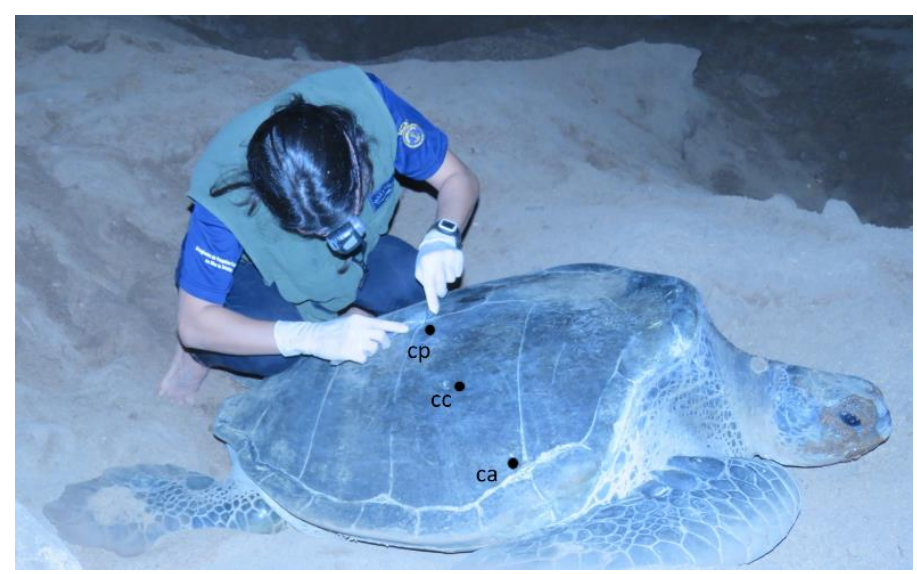

Figura 3.1 Locais de coleta da queratina da carapaça. ca carapaça anterior (tecido mais recente), $c c$ carapaça central, $c p$ carapaça posterior (tecido mais antigo).

No laboratório, em até oito horas após a coleta, separávamos o sangue heparinizado em plasma e células vermelhas por centrifugação (6400 rotações por minuto - RPM - durante 10 minutos). Separávamos os componentes dos ovos (i.e., vitelo, albúmen e casca do ovo) em recipientes diferentes (i.e., copinhos de plástico) para preparação de amostras de cada um deles. Lavávamos todas as amostras de queratina, epiderme, unha e casca do ovo com água destilada. Após a preparação de todos os tecidos, cada um em um eppendorf diferente, deixávamos essas amostras secando na estufa numa temperatura de 50 a $60^{\circ} \mathrm{C}$, por no mínimo $48 \mathrm{~h}$. O tempo de secagem muitas vezes variava de um tecido para o outro. As amostras secas de sangue total e de componentes do sangue, de vitelo e de albúmen foram trituradas em um cadinho. As amostras de queratina, epiderme e casca do ovo foram cortadas em pedaços diminutos com tesoura e misturados (dentro de cada eppendorf). As amostras de unha foram cortadas em pedaços diminutos com cortadores de unha e misturados.

\subsubsection{Metodologia analítica}

\subsubsection{Análise de isótopos estáveis}

Após a preparação dos tecidos, acondicionamos amostras de 0,8 a 1,0 mg (precisão de 0,001 mg) em cápsulas de estanho para análise em espectrômetro de massa de razão isotópica. A 
composição isotópica de carbono e nitrogênio de cada amostra foi determinada no Laboratório de Ecologia Isotópica, do Centro de Energia Nuclear da Agricultura, da Universidade de São Paulo (CENA/USP). As composições isotópicas dos tecidos foram expressas pela denotação $\delta$, definida como partes por mil (\%), e determinadas seguindo a equação:

$\delta^{13} \mathrm{C}$ ou $\delta^{15} \mathrm{~N}=\frac{R_{\text {amostra }}}{R_{\text {padrão }}} \times 100$

onde $\mathrm{R}_{\text {amostra }}$ e $\mathrm{R}_{\text {padrão }}$ é a razão entre o isótopo pesado e o isótopo leve $\left({ }^{13} \mathrm{C} /{ }^{12} \mathrm{C}\right.$ ou $\left.{ }^{15} \mathrm{~N} /{ }^{14} \mathrm{~N}\right)$ na amostra e no padrão, respectivamente. Foi utilizado o padrão internacional Pee Dee Belemnite - PDB para ${ }^{13} \mathrm{C}$ e o $\mathrm{N}_{2}$ atmosférico para ${ }^{15} \mathrm{~N}$.

\subsubsection{Análises estatísticas}

Realizamos análise de variância (ANOVA) e de médias (ANOM) entre os valores de $\delta^{15} \mathrm{~N}$ e entre os valores de $\delta^{13} \mathrm{C}$ de todos os tecidos para avaliarmos a variação entre as assinaturas isotópicas de cada tecido. A ANOM é uma alternativa gráfica à ANOVA e aponta os grupos com médias acima e abaixo da média geral. Por meio de equações de regressão avaliamos as possíveis relações entre a assinatura isotópica de cada tecido $\left(\delta^{15} \mathrm{~N}\right.$ e $\left.\delta^{13} \mathrm{C}\right)$ e as variáveis coletadas em campo (i.e., CCC, LCC e tamanho da ninhada). Optamos pelo modelo quadrático ou linear de acordo com aquele que mais bem explicasse a relação avaliada. Para utilização dos valores de 113C do vitelo e do plasma, usamos uma equação de correção para extração de lipídeos, visto que para ambos os tecidos a razão N/C foi maior que 3,5 (Post et al. 2007). As equações foram fornecidas por Kaufman et al. (2014) e Petitet \& Bugoni (2017) para o vitelo e o plasma, respectivamente.

Realizamos também equações de regressão linear para conversão de valores de $\delta^{15} \mathrm{~N}$ e $\delta^{13} \mathrm{C}$ entre alguns tecidos. A escolha dos tecidos para a formulação das equações de conversão de valores de $\delta^{15} \mathrm{~N}$ e de $\delta^{13} \mathrm{C}$ foi feita considerando os seguintes fatores: $i$ ) facilidade na coleta do tecido, ii) tecidos amplamente utilizados em estudos que envolvem AIE da espécie e iii) altos coeficientes de determinação entre as regressões, a fim de tornar as conversões mais precisas. Para isso, foram testadas todas as regressões entre os pares de tecidos e escolhidos aqueles que melhor abrangessem os fatores mencionados.

\subsection{Resultados}

Coletamos tecidos e quantificamos ninhos de 40 fêmeas de C. mydas, que variaram de 89 a 124,5 cm de comprimento curvilíneo da carapaça (CCC) e 88 a $111 \mathrm{~cm}$ de largura curvilínea da carapaça (LCC). O tamanho dos ninhos variou de 58 a 165 ovos. Não encontramos o ninho de duas fêmeas, para as quais realizamos apenas a biometria seguida da coleta de tecidos. Alguns tecidos (e.g., sangue) de algumas fêmeas não foram coletados por alguma dificuldade na manipulação do indivíduo. Dessa forma, o número de amostras de tecidos foi o seguinte: 34 de 
plasma, 34 de células vermelhas, 36 de unha, 38 de sangue total, 38 de albúmen, 38 de vitelo, 38 de casca do ovo, 39 de carapaça central, 39 de carapaça posterior, 40 de epiderme, 40 de queratina da nadadeira e 40 de carapaça anterior.

A análise de variâncias mostrou que há diferenças entre as médias dos valores de $\delta^{15} \mathrm{Ne}$ de $\delta^{13} \mathrm{C}$ entre os tecidos. Por meio da análise de médias (ANOM), foi possível observar os grupos (tecidos) que estão acima e os que estão abaixo da média geral. Tanto para a $\delta^{15} \mathrm{~N}$ quanto para a $\delta^{13} \mathrm{C}$ (Figuras 3.2 e 3.3, respectivamente), não houve diferença significativa entre a maioria dos tecidos, representados pelos círculos azuis nos gráficos. Já os tecidos representados pelos quadrados vermelhos, apresentam as médias maiores ou menores que a média geral.

De acordo com as análises de média (ANOM) para $\delta^{15} \mathrm{~N}$, não há diferença significativa entre os seguintes tecidos representados pelos círculos azuis: albúmen, carapaça anterior, carapaça central, carapaça posterior, casca do ovo, nadadeira, plasma, unha e vitelo. O valor de $\delta^{15} \mathrm{~N}$ da epiderme é significativamente maior que a média geral, ao passo que as células vermelhas e o sangue total apresentaram $\delta^{15} \mathrm{~N}$ significativamente menor (Figura 3.2). Quanto à ANOM relativa aos valores de $\delta^{13} \mathrm{C}$, não houve diferença significativa entre albúmen, carapaça anterior, carapaça central, carapaça posterior, nadadeira, plasma e unha. Casca do ovo e epiderme apresentaram $\delta^{13} \mathrm{C}$ significativamente maior que a média geral. Células vermelhas, sangue total e vitelo apresentaram $\delta^{13} \mathrm{C}$ significativamente menor (Figura 3.3).

No gráfico de dispersão (Figura 3.4) com os valores de isótopos da unha e do sangue total, é possível visualizar a amplitude de valores tanto de $\delta^{15} \mathrm{~N}$ (variando de $1,24 \%$ a $13,40 \%$ ) quanto de $\delta^{13} \mathrm{C}$ (variando de $-25,23 \%$ a $-12,89 \%$ ). Todos os outros tecidos analisados neste estudo apresentam valores dentro dessa amplitude.

Para o plasma, a casca do ovo e a queratina da carapaça anterior, apresentamos equações de regressão para conversão do valor de $\delta^{15} \mathrm{~N}$ de um tecido para o outro (Tabela 3.1). O menor coeficiente foi $\mathrm{r}^{2}=0,861$ e o maior foi $\mathrm{r}^{2}=0,929$. Para os mesmos tecidos, apresentamos as equações para conversão dos valores de $\delta^{13} \mathrm{C}$ (Tabela 3.2), sendo o menor coeficiente de determinação $\mathrm{r}^{2}=0,495$ e o maior $\mathrm{r}^{2}=0,794$. As Tabelas 3.3 e 3.4 apresentam as equações de conversão de valores de $\delta^{15} \mathrm{~N}$ e de $\delta^{13} \mathrm{C}$ para sangue total, plasma e células vermelhas. Os valores dos coeficientes de determinação variaram de $\mathrm{r}^{2}=0,793 \mathrm{a} \mathrm{r}^{2}=0,961$ para $\delta^{15} \mathrm{~N}$. Para $\delta^{13} \mathrm{C}$, os valores dos coeficientes variaram de $\mathrm{r}^{2}=0,802$ a $^{2}=0,930$.

As relações do $\delta^{15} \mathrm{~N}$ de todos os 12 tecidos com o CCC (Figura 3.5) e com o tamanho da ninhada (Figura 3.7) foram positivamente significativas. Já com a LCC, sete das 12 relações foram significativas, e também positivas (Figura 3.6). Quanto ao $\delta^{13} \mathrm{C}$, apenas quatro tecidos apresentaram relações significativas e somente com a variável LCC (Figura 3.8), apresentando baixos coeficientes de determinação $\left(\mathrm{r}^{2}\right)$. Essas relações também foram todas positivas. As Tabelas 3.7 e 3.8 apresentam os coeficientes das equações de regressão $\left(\delta^{15} \mathrm{~N}\right.$ e $\delta^{13} \mathrm{C}$, 
respectivamente), e os valores de $\mathrm{p}, \mathrm{r}^{2}$ e gl para todas as relações verificadas, incluindo aquelas não significativas.

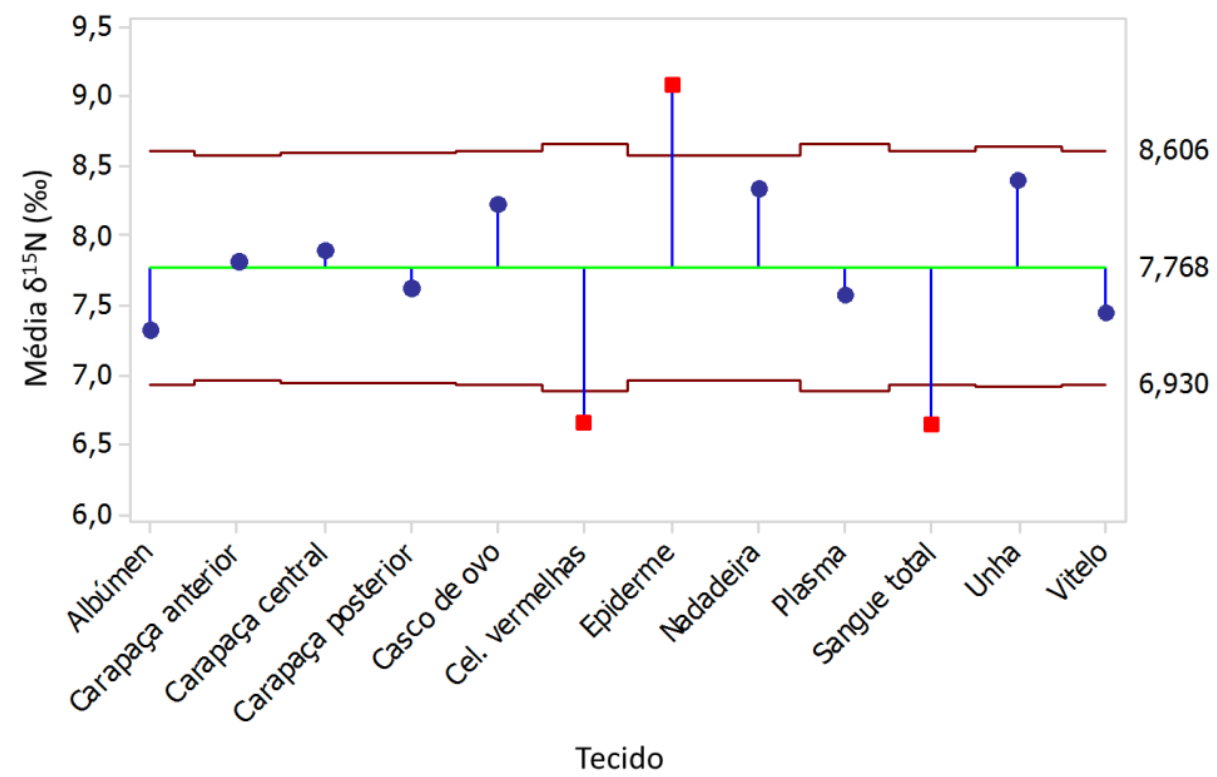

Figura 3.2 Análise de médias (ANOM) de $\delta^{15} \mathrm{~N}$ dos tecidos. (ANOVA: $\mathrm{F}=5,38$; $\mathrm{P}<0,001 ; \mathrm{gl}=453)$.

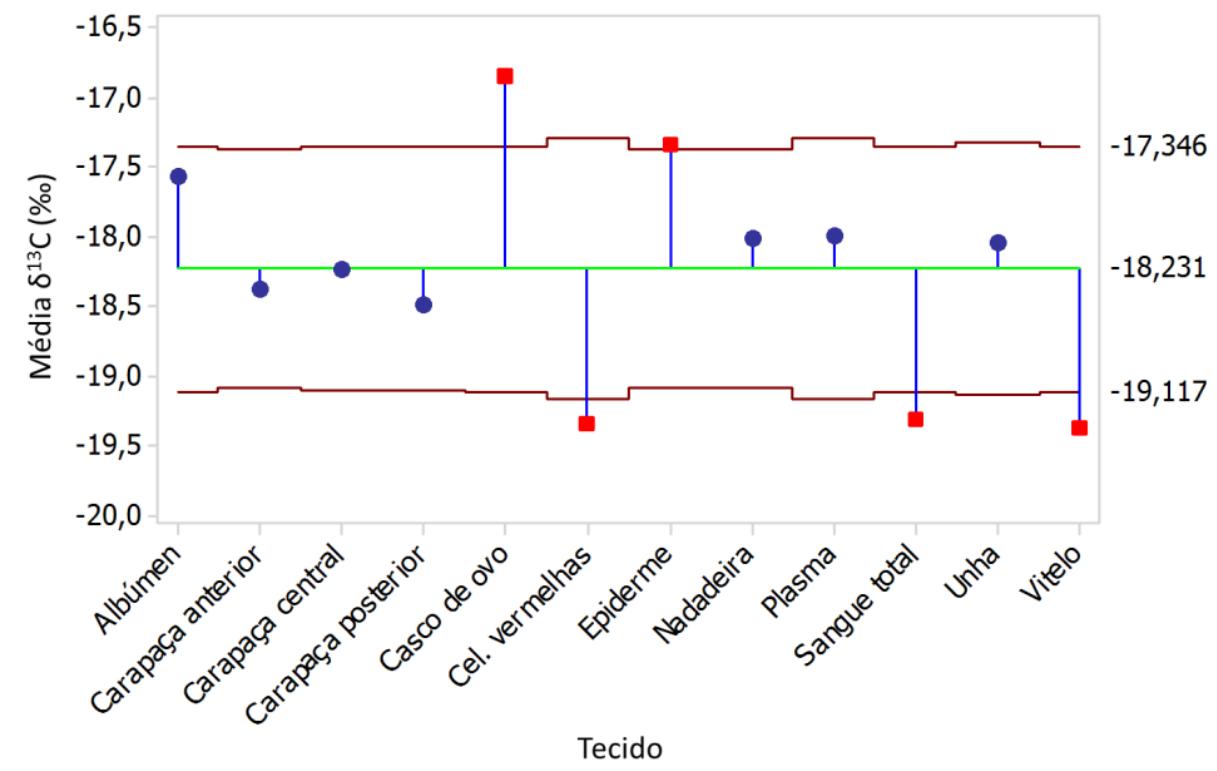

Figura 3.3 Assinatura isotópica de $\delta^{13} \mathrm{C}$ dos tecidos (ANOVA: $\mathrm{F}=6,14 ; \mathrm{p}<0,001$; $\mathrm{gl}=533)$ 


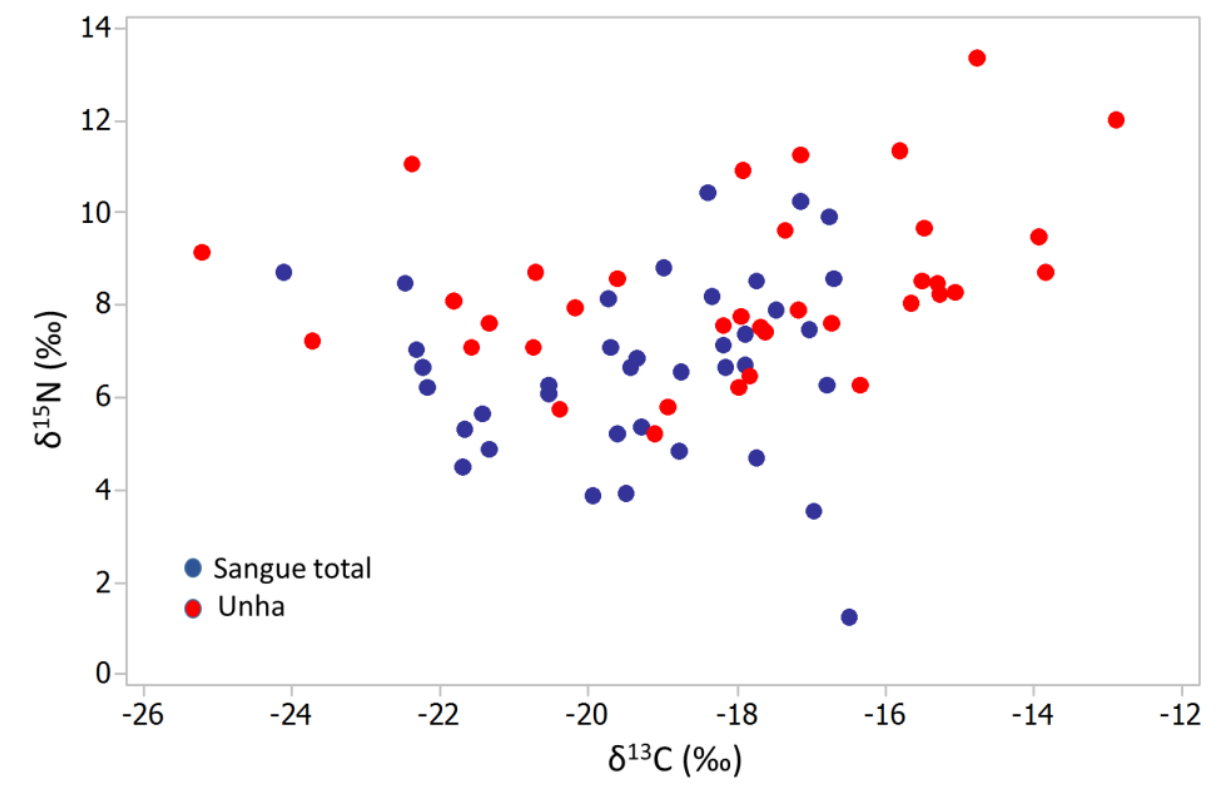

Figura 3.4 Valores de $\delta 15 \mathrm{~N}$ e $\delta 13 \mathrm{C}$ abrangendo os valores mais baixos e mais altos para ambos os isótopos. 
Tabela 3.1 Equações de regressão entre tecidos para $\delta^{15} \mathrm{~N}(\mathrm{y}=\mathrm{a}+\mathrm{bx})$.

\begin{tabular}{|c|c|c|c|}
\hline \multirow[b]{2}{*}{$\mathrm{y}$} & \multicolumn{3}{|c|}{$\mathrm{x}$} \\
\hline & Plasma & Carapaça anterior & Casca do ovo \\
\hline $\begin{array}{c}\text { Plasma } \\
\text { Carapaça anterior }\end{array}$ & $\mathrm{y}=0,1400+0,9953 \times\left(\mathrm{r}^{2}=0,905 ; \mathrm{p}<0,001\right)$ & $\mathrm{y}=0,5934+0,9092 \times\left(\mathrm{r}^{2}=0,905 ; \mathrm{p}<0,001\right)$ & $\begin{array}{l}y=-0,2877+0,9556 \times\left(r^{2}=0,929 ; p<0,001\right) \\
y=-0,3289+0,9786 \times\left(r^{2}=0,861 ; p<0,001\right)\end{array}$ \\
\hline Casco do ovo & $\mathrm{y}=0,8543+0,9725 \times\left(\mathrm{r}^{2}=0,929 ; \mathrm{p}<0,001\right)$ & $\mathrm{y}=1,431+0,8800 \times\left(\mathrm{r}^{2}=0,861 ; \mathrm{p}<0,001\right)$ & , \\
\hline
\end{tabular}

Tabela 3.2 Equações de regressão entre tecidos para $\delta^{13} \mathrm{C}(\mathrm{y}=\mathrm{a}+\mathrm{bx})$.

\begin{tabular}{|c|c|c|c|}
\hline $\mathrm{y}$ & \multicolumn{3}{|c|}{$\mathrm{x}$} \\
\cline { 2 - 5 } & Plasma & Carapaça anterior & $\mathrm{Casca}$ do ovo \\
\hline Plasma & - & $\mathrm{y}=-8,461+0,5179 \times\left(\mathrm{r}^{2}=0,698 ; \mathrm{p}<0,001\right)$ & $-8,015+0,5927 \mathrm{x}\left(\mathrm{r}^{2}=0,794 ; \mathrm{p}<0,001\right)$ \\
Carapaça anterior & $\mathrm{y}=5,845+1,348 \times\left(\mathrm{r}^{2}=0,698 ; \mathrm{p}<0,001\right)$ & - & $\mathrm{y}=-5,605+0,7619 \times\left(\mathrm{r}^{2}=0,495 ; \mathrm{p}<0,001\right)$ \\
Casco do ovo & $\mathrm{y}=7,250+1,339 \times\left(\mathrm{r}^{2}=0,794 ; \mathrm{p}<0,001\right)$ & $\mathrm{y}=-4,869+0,6496 \mathrm{x}\left(\mathrm{r}^{2}=0,495 ; \mathrm{p}<0,001\right)$ & - \\
\hline
\end{tabular}

Tabela 3.3 Equações de regressão entre componentes do sangue $\delta^{15} \mathrm{~N}(\mathrm{y}=\mathrm{a}+\mathrm{bx})$.

\begin{tabular}{|c|c|c|c|}
\hline \multirow[b]{2}{*}{$\mathrm{y}$} & \multicolumn{3}{|c|}{$\mathrm{x}$} \\
\hline & Sangue total & Células vermelhas & Plasma \\
\hline $\begin{array}{l}\text { Sangue total } \\
\text { Células vermelhas } \\
\text { Plasma }\end{array}$ & $\begin{array}{l}y=0,1433+1,010 \times\left(r^{2}=0,793 ; p<0,001\right) \\
y=1.774+0.8995 \times\left(r^{2}=0.812 ; p<0,001\right)\end{array}$ & $\begin{array}{c}y=1,217+0,7849 \times\left(r^{2}=0,793 ; p<0,001\right) \\
- \\
y=1,826+0,8657 \times\left(r^{2}=0,961 ; p>0,001\right)\end{array}$ & $\begin{array}{c}y=-0,3987+0,9032 \times\left(r^{2}=0,812 ; p<0,001\right) \\
y=-1,765+1,110 \times\left(r^{2}=0,961 ; p<0,001\right)\end{array}$ \\
\hline
\end{tabular}

Tabela 3.4. Equações de regressão entre componentes do sangue para $\delta^{13} \mathrm{C}(\mathrm{y}=\mathrm{a}+\mathrm{bx})$.

\begin{tabular}{|c|c|c|c|}
\hline \multirow{2}{*}{$\mathrm{y}$} & Sangue total & Células vermelhas & Plasma \\
\cline { 2 - 5 } & - & $\mathrm{y}=-2,887+0,8556 \times\left(\mathrm{r}^{2}=0,802 ; \mathrm{p}<0,001\right)$ & $\mathrm{y}=5,336+1,377 \mathrm{x}\left(\mathrm{r}^{2}=0,808 ; \mathrm{p}<0,001\right)$ \\
\hline $\begin{array}{c}\text { Sangue total } \\
\text { Célus vermelhas }\end{array}$ & $\mathrm{y}=-1,128+0,9373 \mathrm{x}\left(\mathrm{r}^{2}=0,802 ; \mathrm{p}<0,001\right)$ & - & $\mathrm{y}=8,480+1,547 \mathrm{x}\left(\mathrm{r}^{2}=0,930 ; \mathrm{p}<0,001\right)$ \\
\hline
\end{tabular}


Tabela 3.5 Equações de regressão linear entre tecidos para $\delta^{15} \mathrm{~N}(\mathrm{y}=\mathrm{a}+\mathrm{bx})$.

\begin{tabular}{|c|c|c|c|}
\hline \multirow{2}{*}{$\mathrm{y}$} & Epiderme & Células vermelhas & Plasma \\
\cline { 2 - 4 } & - & $\mathrm{y}=2,770+0,9122 \times\left(\mathrm{r}^{2}=0,905 ; \mathrm{p}<0,001 ; \mathrm{gl}=31\right.$ & $\mathrm{y}=1,206+1,009 \times\left(\mathrm{r}^{2}=0,903 ; \mathrm{p}<0,001 ; \mathrm{gl}=31\right)$ \\
Epiderme & - & & $\mathrm{y}=-1,765+1,110 \times \mathrm{x}\left(\mathrm{r}^{2}=0,961 ; \mathrm{p}<0,001 ; \mathrm{gl}=33\right)$ \\
$\begin{array}{c}\text { Células vermelhas } \\
\text { Plasma }\end{array}$ & $\mathrm{y}=-2,093+0,9918 \times\left(\mathrm{r}^{2}=0,905, \mathrm{p}<0,001 ; \mathrm{gl}=31\right)$ & & - \\
\hline
\end{tabular}

Tabela 3.6 Equações de regressão linear entre tecidos para $\delta^{13} \mathrm{C}(\mathrm{y}=\mathrm{a}+\mathrm{bx})$.

\begin{tabular}{|c|c|c|c|}
\hline \multirow[b]{2}{*}{$\mathrm{y}$} & \multicolumn{3}{|c|}{$\mathrm{x}$} \\
\hline & Epiderme & Células vermelhas & Plasma \\
\hline $\begin{array}{c}\text { Epiderme } \\
\text { Células vermelhas } \\
\text { Plasma }\end{array}$ & $\begin{array}{l}- \\
y=0,741+1,158 \times\left(r^{2}=0,892 ; p<0,001 ; g l=31\right) \\
y=-5,604+0,7132 \times\left(r^{2}=, 989 ; p<0,001 ; g l=31\right)\end{array}$ & $\begin{array}{c}\mathrm{y}=-2,443+0,7704 x\left(\mathrm{r}^{2}=0,892 ; \mathrm{p}<0,001 ; \mathrm{gl}=31\right) \\
- \\
\mathrm{y}=-6,358+0,6014 x\left(\mathrm{r}^{2}=0,930 ; \mathrm{p}<0,001 ; \mathrm{gl}=33\right)\end{array}$ & $\begin{array}{c}\mathrm{y}=5,291+1,25913 \times\left(\mathrm{r}^{2}=0,898 ; \mathrm{p}<0,001 ; \mathrm{gl}=31\right) \\
\mathrm{y}=8,480+1,547 \times\left(\mathrm{r}^{2}=0,930 ; \mathrm{p}<0,001, \mathrm{gl}=33\right) \\
-\end{array}$ \\
\hline
\end{tabular}



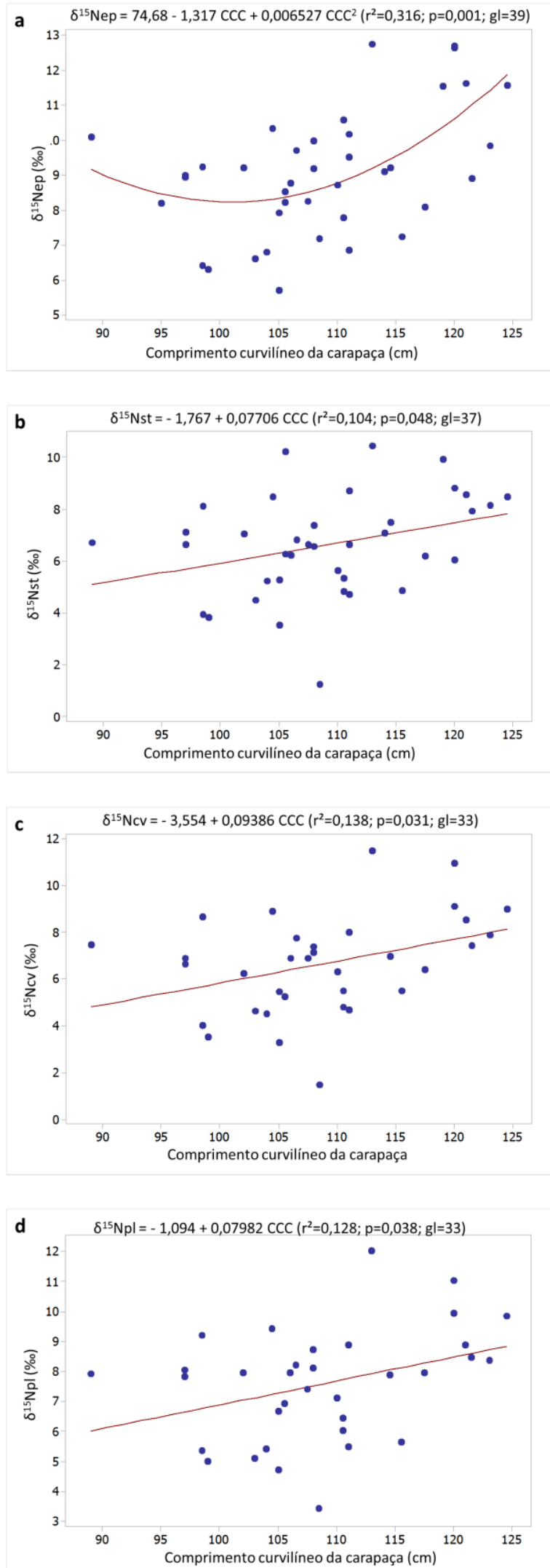
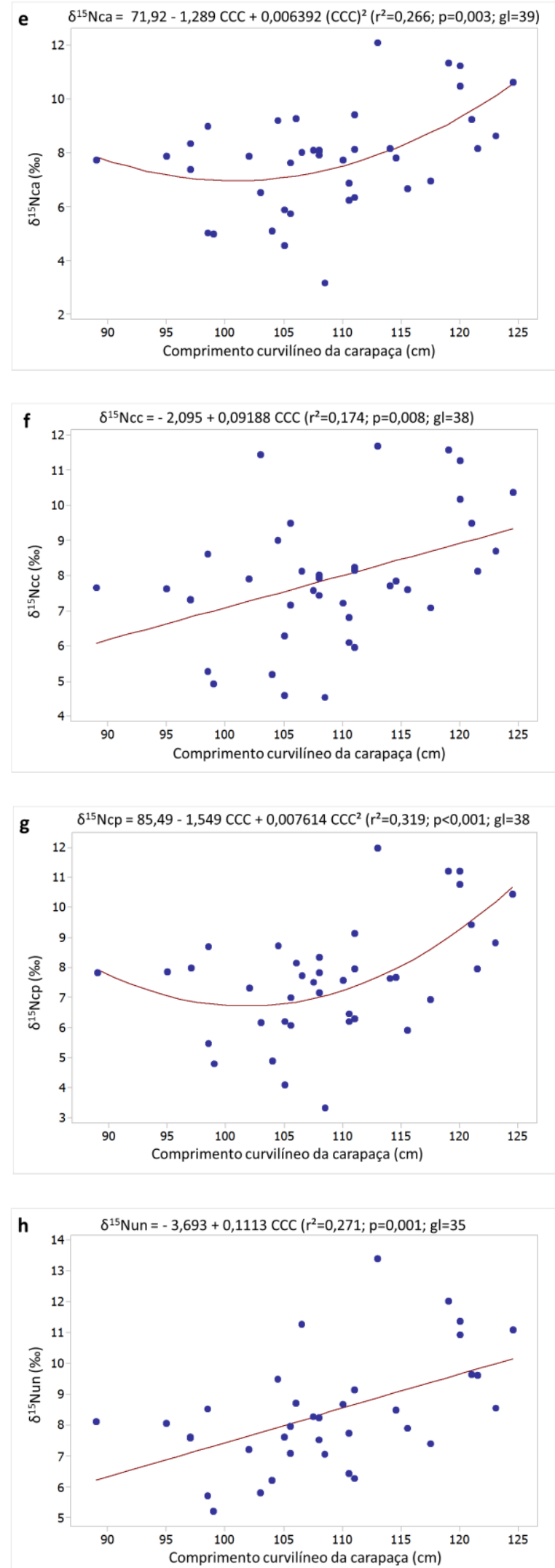

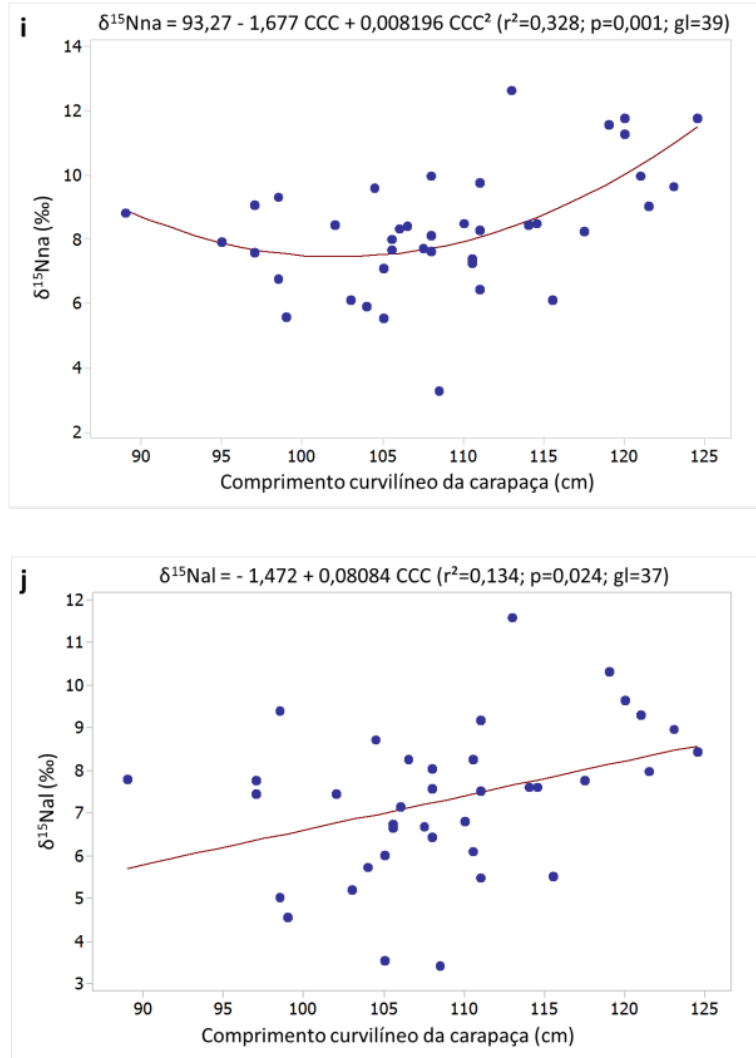

Figura 3.5 Relação entre comprimento curvilíneo da carapaça (CCC) e $\delta^{15} \mathrm{~N}$ de (a) ep epiderme (b) st sangue total (c) $c v$ células vermelhas (d) $p l$ plasma (e) $c a$ carapaça anterior (f) $c c$ carapaça central (g) $c p$ carapaça posterior (h) un unha (i) $n a$
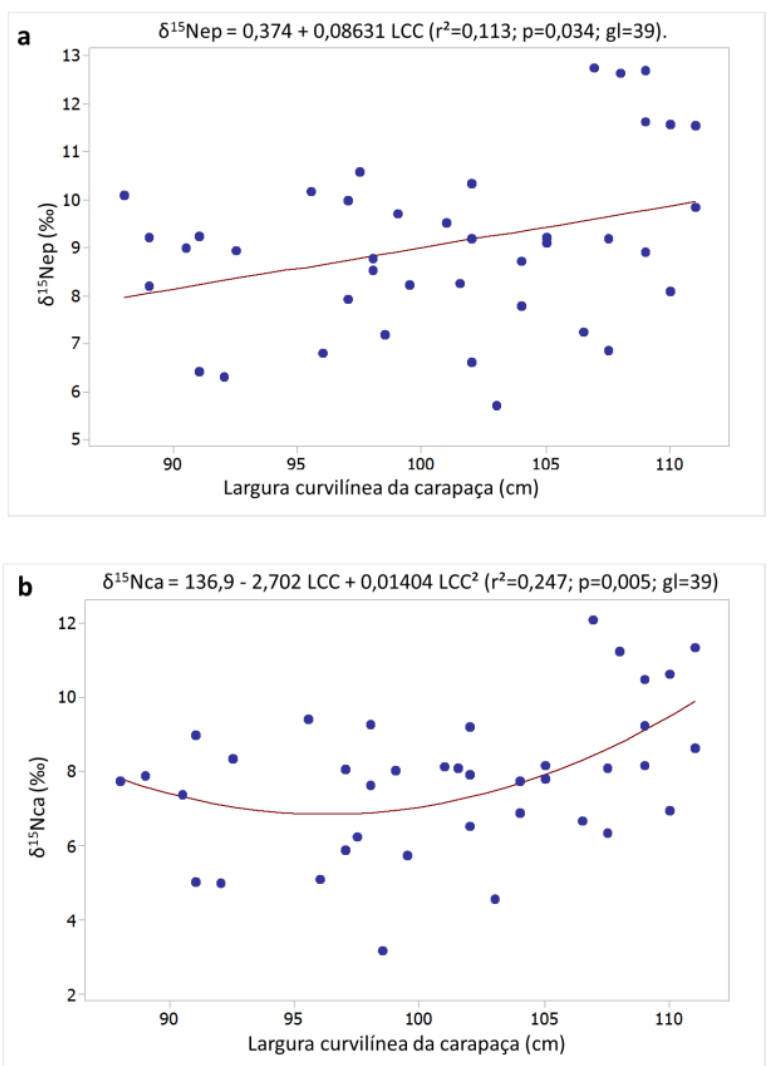
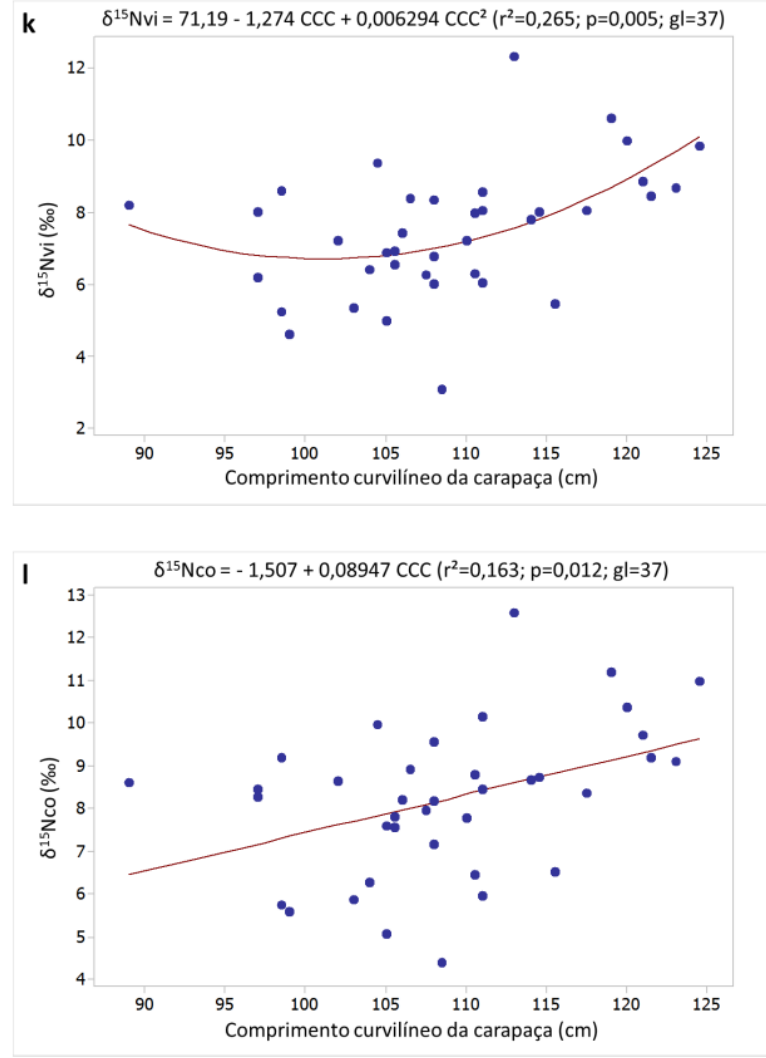

nadadeira (j) al albúmen (k) vi vitelo (l) co casca do ovo. As equações nos gráficos são referentes a cada relação. $r^{2}$ : coeficiente de determinação da regressão linear, ou quadrática, $p$ : p-valor, $g l$ : graus de liberdade.
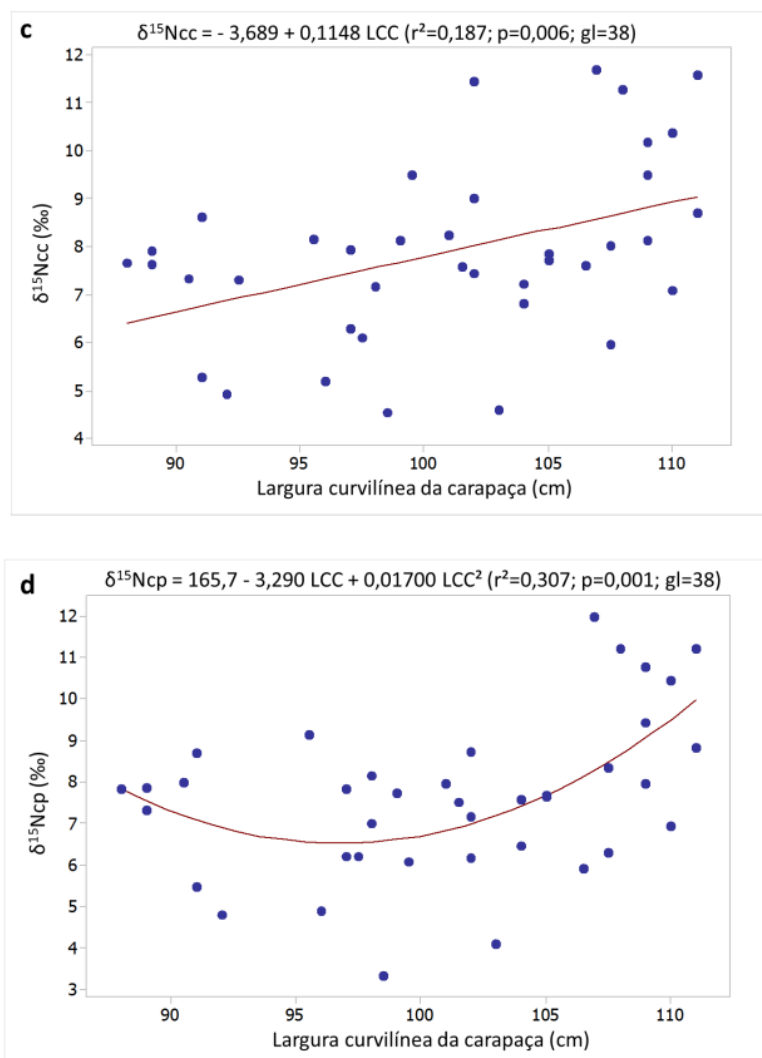

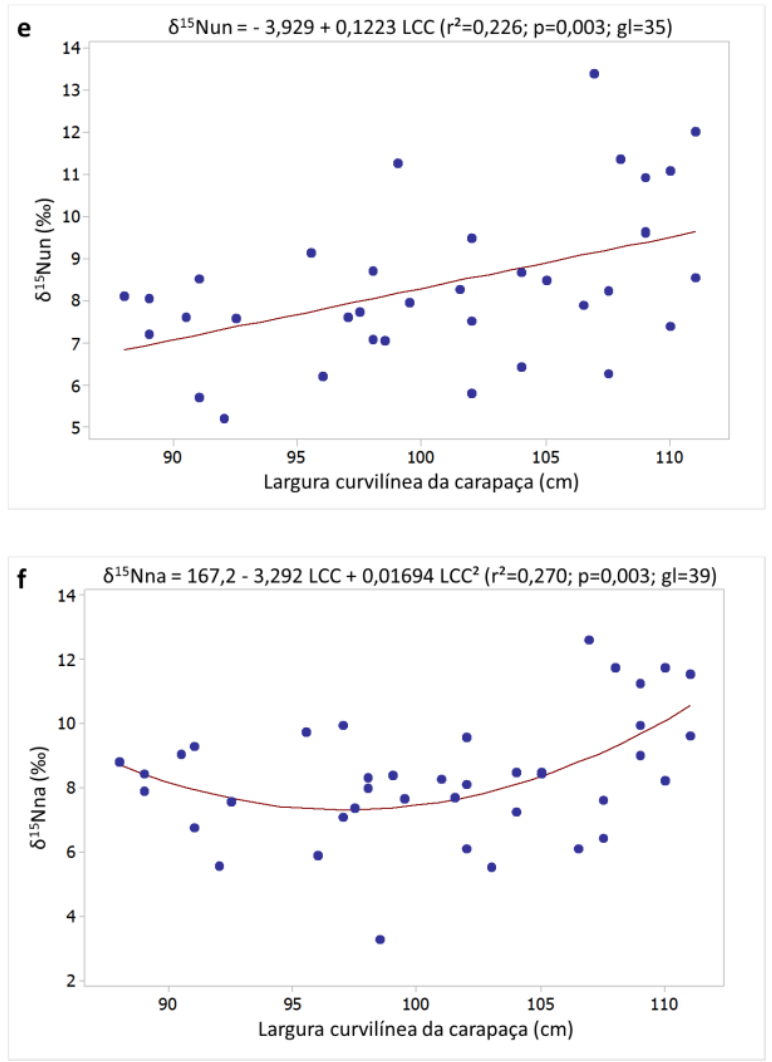

Figura 3.6 Relação entre largura curvilínea da carapaça (LCC) e $\delta^{15} \mathrm{~N}$ de (a) ep epiderme (b) $c a$ carapaça anterior (c) $c c$ carapaça central (d) $c p$ carapaça posterior (e) un unha (f) $n a$
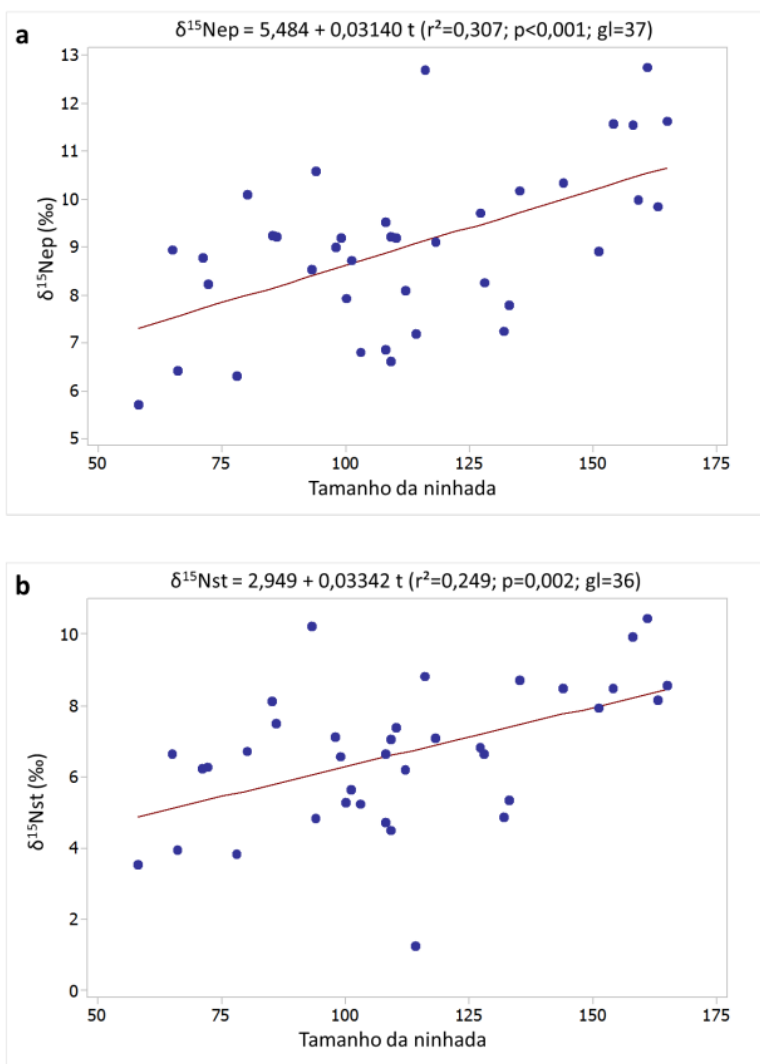

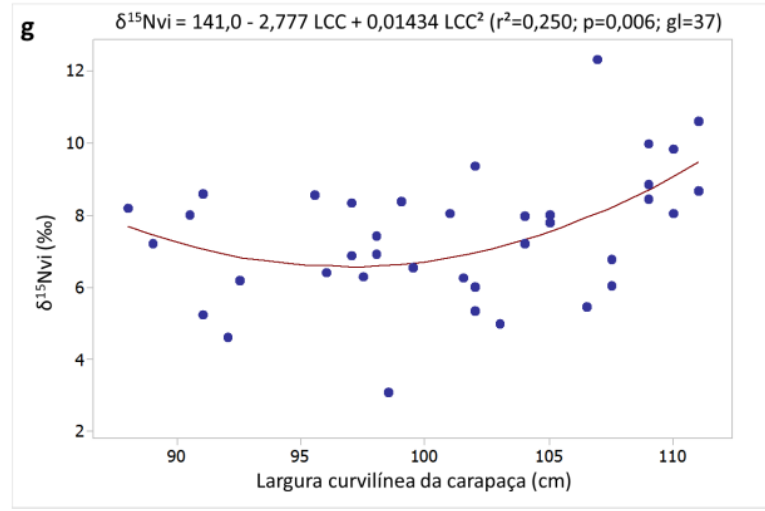

nadadeira (g) vi vitelo. As equações nos gráficos são referentes a cada relação. $r^{2}$ : coeficiente de determinação da regressão linear, ou quadrática, $p$ : $\mathrm{p}$-valor, $g l$ : graus de liberdade.
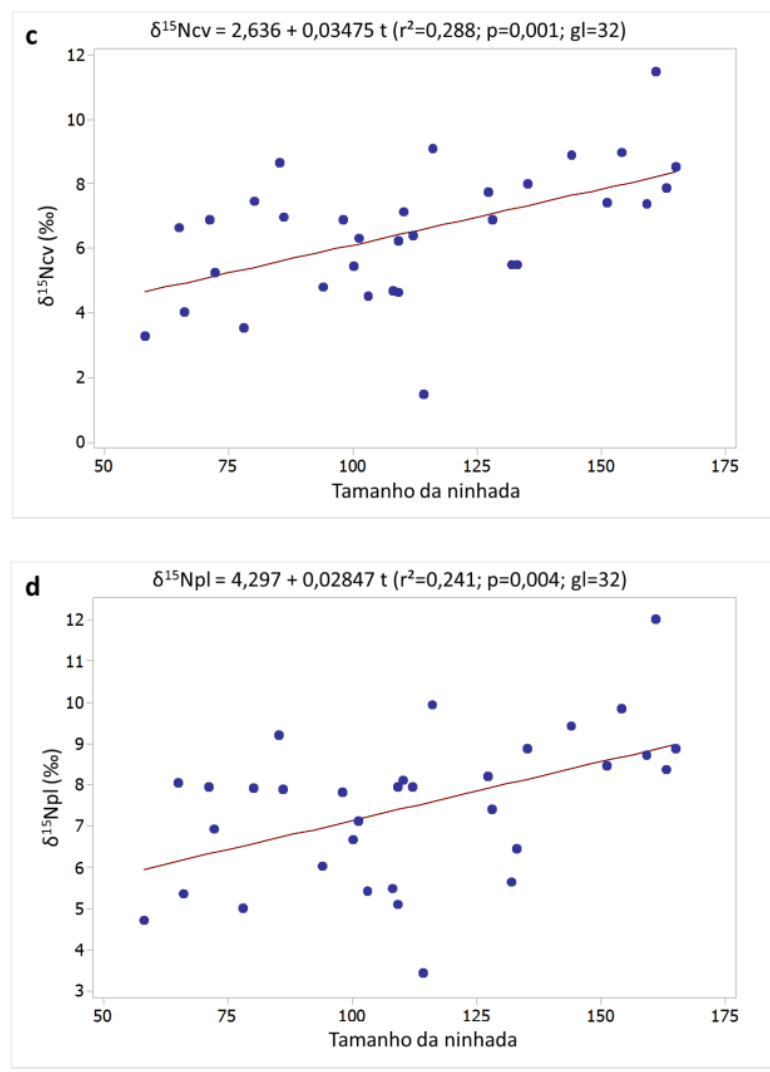

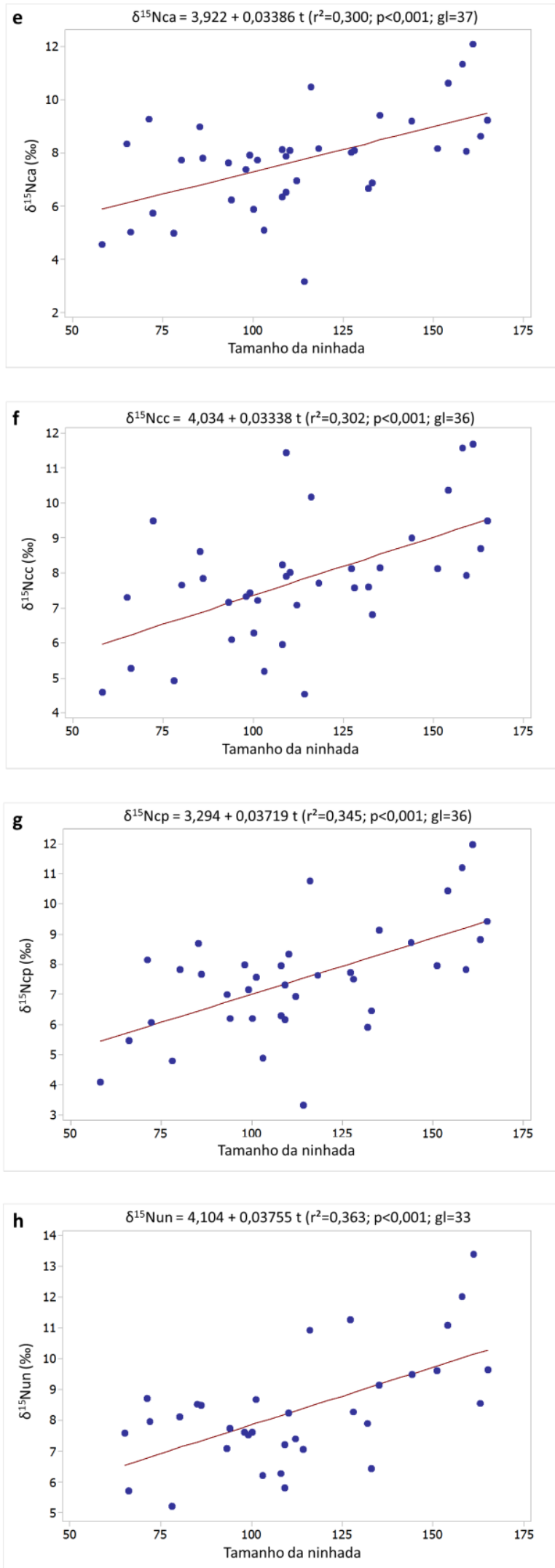

Figura 3.7 Relação entre tamanho da ninhada (t) e $\delta^{15} \mathrm{~N}$ de (a) $e p$ epiderme (b) $s t$ sangue total (c) $c v$ células vermelhas (d) $p l$ plasma (e) $c a$ carapaça anterior (f) $c c$ carapaça central (g) $c p$ carapaça posterior (h) un unha (i) na nadadeira (j) al albúmen
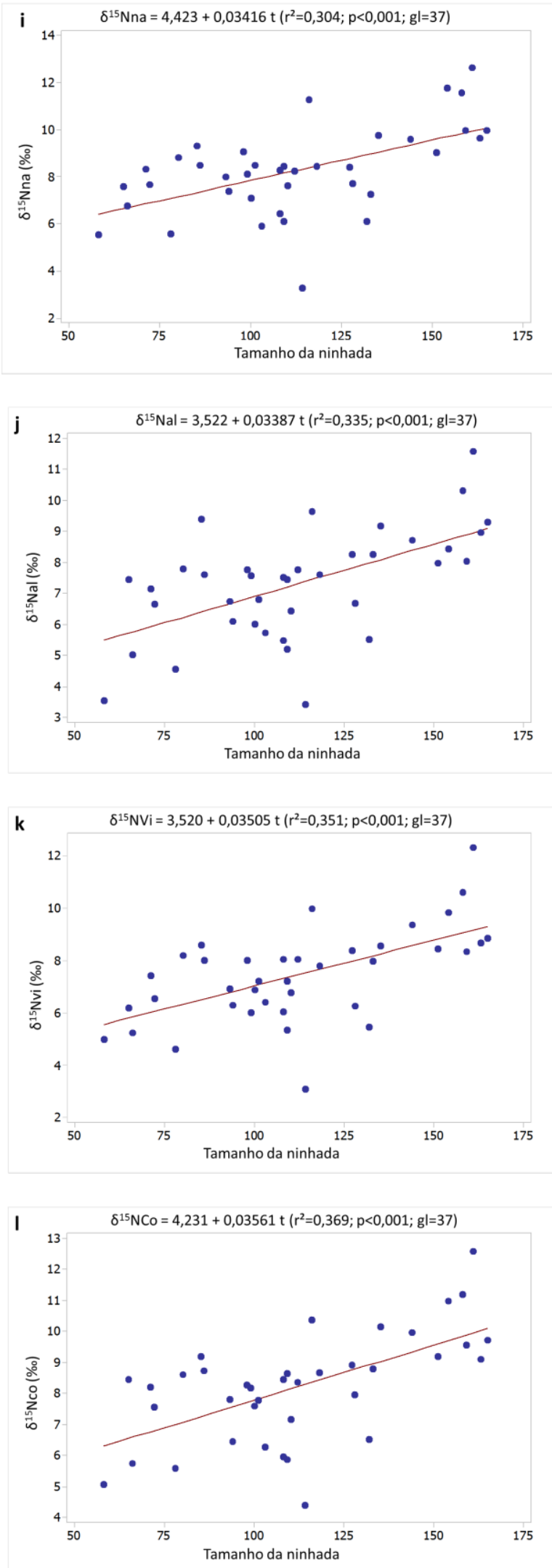

(k) vi vitelo (l) co casca do ovo. As equações nos gráficos são referentes a cada relação. $r^{2}$ : coeficiente de determinação da regressão linear, ou quadrática, $p$ : p-valor, $g l$ : graus de liberdade. 
Tabela 3.5 Equações de regressão entre $\delta^{15} \mathrm{~N}$ e variáveis biométricas de Chelonia mydas $\left(y=a+b x+c x^{2}\right)$. CCC: comprimento curvilíneo da carapaça; LCC: largura curvilínea da carapaça; t: tamanho da ninhada, ep: epiderme, st: sangue total, cv: células vermelhas, pl: plasma, ca: carapaça anterior; cc: carapaça central; cp: carapaça posterior; un: unha; na: nadadeira; al: albúmen; vi: vitelo; co: casca do ovo.

\begin{tabular}{|c|c|c|c|c|c|c|c|}
\hline y & $\mathbf{x}$ & a & b & c & p & $r^{2}$ & gl \\
\hline$\delta^{15} \mathrm{Nep}$ & $\mathrm{CCC}$ & 74,68 & $-1,317$ & 0,006527 & 0,001 & 0,316 & 39 \\
\hline$\delta^{15} \mathrm{Nep}$ & LCC & 0,374 & 0,08631 & 0 & 0,034 & 0,113 & 39 \\
\hline$\delta^{15} \mathrm{Nep}$ & $\mathrm{t}$ & 5,484 & 0,0314 & 0 & $<0,001$ & 0,307 & 37 \\
\hline$\delta^{15} \mathrm{Nst}$ & $\mathrm{CCC}$ & $-1,767$ & 0,07706 & 0 & 0,048 & 0,104 & 37 \\
\hline$\delta^{15} \mathrm{Nst}$ & LCC & $-1,387$ & 0,07927 & 0 & 0,096 & 0,075 & 37 \\
\hline$\delta^{15} \mathrm{Nst}$ & $\mathrm{t}$ & 2,949 & 0,03342 & 0 & 0,002 & 0,249 & 36 \\
\hline$\delta^{15} \mathrm{Ncv}$ & $\mathrm{CCC}$ & $-3,554$ & 0,09386 & 0 & 0,031 & 0,138 & 33 \\
\hline$\delta^{15} \mathrm{Ncv}$ & LCC & $-3,210$ & 0,09779 & 0 & 0,067 & 0,101 & 33 \\
\hline$\delta^{15} \mathrm{Ncv}$ & $\mathrm{t}$ & 2,636 & 0,03475 & 0 & 0,001 & 0,288 & 32 \\
\hline$\delta^{15} \mathrm{Npl}$ & $\mathrm{CCC}$ & $-1,094$ & 0,07982 & 0 & 0,032 & 0,128 & 33 \\
\hline$\delta^{15} \mathrm{Npl}$ & LCC & 0,069 & 0,07452 & 0 & 0,116 & 0,075 & 33 \\
\hline$\delta^{15} \mathrm{Npl}$ & $\mathrm{t}$ & 4,297 & 0,02847 & 0 & 0,004 & 0,241 & 32 \\
\hline$\delta^{15} \mathrm{Nca}$ & $\mathrm{CCC}$ & 71,92 & $-1,289$ & 0,006392 & 0,003 & 0,266 & 39 \\
\hline$\delta^{15} \mathrm{Nca}$ & LCC & 136,9 & $-2,702$ & 0,01404 & 0,005 & 0,247 & 39 \\
\hline$\delta^{15} \mathrm{Nca}$ & $\mathrm{t}$ & 3,922 & 0,03386 & 0 & $<0,001$ & 0,300 & 37 \\
\hline$\delta^{15} \mathrm{Ncc}$ & $\mathrm{CCC}$ & $-2,095$ & 0,09188 & 0 & 0,008 & 0,174 & 38 \\
\hline$\delta^{15} \mathrm{Ncc}$ & LCC & $-3,689$ & 0,1148 & 0 & 0,006 & 0,187 & 38 \\
\hline$\delta^{15} \mathrm{Ncc}$ & $\mathrm{t}$ & 4,034 & 0,03338 & 0 & $<0,001$ & 0,302 & 36 \\
\hline$\delta^{15} \mathrm{Ncp}$ & $\mathrm{CCC}$ & 85,49 & $-1,549$ & 0,007614 & 0,0001 & 0,319 & 38 \\
\hline$\delta^{15} \mathrm{Ncp}$ & LCC & 165,7 & $-3,290$ & 0,017 & 0,007 & 0,307 & 38 \\
\hline$\delta^{15} \mathrm{Ncp}$ & $\mathrm{t}$ & 3,294 & 0,03719 & 0 & $<0,001$ & 0,345 & 36 \\
\hline$\delta^{15}$ Nun & $\mathrm{CCC}$ & $-3,693$ & 0,1113 & 0 & 0,001 & 0,271 & 35 \\
\hline$\delta^{15}$ Nun & LCC & $-3,929$ & 0,1223 & 0 & 0,003 & 0,226 & 35 \\
\hline$\delta^{15}$ Nun & $t$ & 4,104 & 0,03755 & & $<0,001$ & 0,363 & 33 \\
\hline$\delta^{15} \mathrm{Nna}$ & $\mathrm{CCC}$ & 93,27 & $-1,677$ & 0,008196 & 0,001 & 0,328 & 39 \\
\hline$\delta^{15} \mathrm{Nna}$ & LCC & 167,2 & $-3,292$ & 0,01694 & 0,003 & 0,270 & 39 \\
\hline$\delta^{15} \mathrm{Nna}$ & $\mathrm{t}$ & 4,423 & 0,03416 & 0 & $<0,001$ & 0,304 & 37 \\
\hline$\delta^{15} \mathrm{Nal}$ & $\mathrm{CCC}$ & $-1,472$ & 0,08084 & 0 & 0,024 & 0,134 & 37 \\
\hline$\delta^{15} \mathrm{Nal}$ & LCC & $-0,047$ & 0,07298 & 0 & 0,093 & 0,077 & 37 \\
\hline$\delta^{15} \mathrm{Nal}$ & $\mathrm{t}$ & 3,522 & 0,03387 & 0 & $<0,001$ & 0,335 & 37 \\
\hline$\delta^{15} \mathrm{Nvi}$ & $\mathrm{CCC}$ & 71,19 & $-1,274$ & 0,006294 & 0,005 & 0,265 & 37 \\
\hline$\delta^{15} \mathrm{Nvi}$ & LCC & 141,0 & $-2,777$ & 0,01434 & 0,006 & 0,250 & 37 \\
\hline$\delta^{15} \mathrm{Nvi}$ & $t$ & 3,520 & 0,03505 & 0 & $<0,001$ & 0,351 & 37 \\
\hline$\delta^{15} \mathrm{NcO}$ & $\mathrm{CCC}$ & $-1,507$ & 0,08947 & 0 & 0,012 & 0,163 & 37 \\
\hline$\delta^{15} \mathrm{Nco}$ & LCC & 0,168 & 0,07980 & 0 & 0,066 & 0,091 & 37 \\
\hline$\delta^{15} \mathrm{Nco}$ & $\mathrm{t}$ & 4,231 & 0,03561 & 0 & $<0,001$ & 0,369 & 37 \\
\hline
\end{tabular}



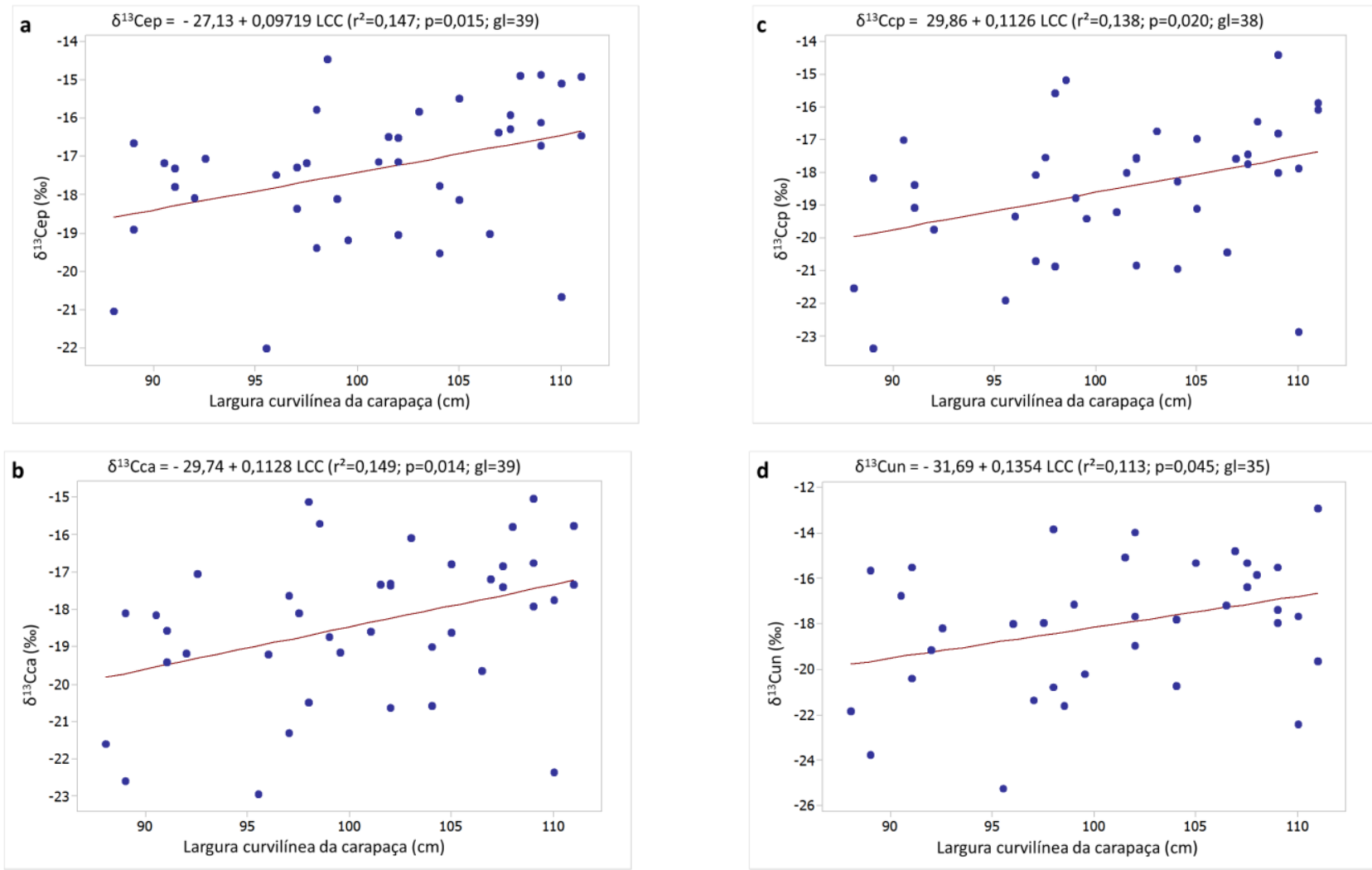

Figura 3.8 Relação entre largura curvilínea da carapaça (LCC) e $\delta^{13} \mathrm{C}$ de (a) ep epiderme (b) $c a$ carapaça anterior (c) $\boldsymbol{c p}$ carapaça posterior (d) un unha. As equações nos gráficos são

referentes a cada relação. $r^{2}$ : coeficiente de determinação da regressão linear, $p$ : $\mathrm{p}$-valor, $g l$ : graus de liberdade. 
Tabela 3.6 Equações de regressão entre $\delta^{13} \mathrm{C}$ e variáveis biométricas de Chelonia mydas ( $\mathrm{y}=\mathrm{a}+\mathrm{bx})$. CCC: comprimento curvilíneo da carapaça; LCC: largura curvilínea da carapaça; $\mathrm{t}$ : tamanho da ninhada; ep: epiderme; st: sangue total; cv: células vermelhas; pl: plasma; ca: carapaça anterior; cc: carapaça central; cp: carapaça posterior; un: unha; na: nadadeira; al: albúmen; vi: vitelo; co: casca do ovo.

\begin{tabular}{|c|c|c|c|c|c|c|}
\hline y & $\mathbf{x}$ & a & $\mathbf{b}$ & $\mathbf{p}$ & $r^{2}$ & gl \\
\hline 13CEp & $\mathrm{CCC}$ & $-24,11$ & 0,06234 & 0,064 & 0,088 & 39 \\
\hline 13CEp & LCC & $-27,13$ & 0,09719 & 0,015 & 0,147 & 39 \\
\hline 13CEp & $\mathrm{t}$ & $-18,18$ & 0,006791 & 0,481 & 0,014 & 37 \\
\hline $13 \mathrm{CSt}$ & $\mathrm{CCC}$ & $-20,30$ & 0,00907 & 0,822 & 0,001 & 37 \\
\hline $13 \mathrm{CSt}$ & LCC & $-24,63$ & 0,05255 & 0,278 & 0,033 & 37 \\
\hline $13 \mathrm{CSt}$ & $\mathrm{t}$ & $-19,60$ & 0,00294 & 0,797 & 0,002 & 36 \\
\hline $13 \mathrm{CCV}$ & $\mathrm{CCC}$ & $-21,44$ & 0,01921 & 0,663 & 0,006 & 33 \\
\hline $13 C \mathrm{CV}$ & LCC & $-25,89$ & 0,06484 & 0,221 & 0,046 & 33 \\
\hline $13 \mathrm{CCV}$ & $\mathrm{t}$ & $-19,24$ & - 0,00154 & 0,899 & 0,001 & 32 \\
\hline $13 \mathrm{CPI}$ & $\mathrm{CCC}$ & $-17,96$ & $-0,00032$ & 0,991 & 0,000 & 33 \\
\hline $13 \mathrm{CPI}$ & LCC & $-20,53$ & 0,02516 & 0,450 & 0,018 & 33 \\
\hline $13 \mathrm{CPI}$ & $\mathrm{t}$ & $-17,91$ & $-0,001092$ & 0,885 & 0,001 & 32 \\
\hline $13 \mathrm{CCa}$ & $\mathrm{CCC}$ & $-25,49$ & 0,06551 & 0,092 & 0,073 & 39 \\
\hline $13 \mathrm{CCa}$ & LCC & $-29,74$ & 0,1128 & 0,014 & 0,149 & 39 \\
\hline $13 \mathrm{CCa}$ & $\mathrm{t}$ & $-19,08$ & 0,00571 & 0,610 & 0,007 & 37 \\
\hline $13 \mathrm{CCc}$ & $\mathrm{CCC}$ & $-23,98$ & 0,05287 & 0,193 & 0,045 & 38 \\
\hline $13 \mathrm{CCc}$ & LCC & $-26,22$ & 0,07921 & 0,103 & 0,070 & 38 \\
\hline $13 \mathrm{CCc}$ & $\mathrm{t}$ & $-20,62$ & 0,02056 & 0,079 & 0,086 & 36 \\
\hline $13 C C p$ & $\mathrm{CCC}$ & $-26,59$ & 0,07432 & 0,071 & 0,086 & 38 \\
\hline $13 C C p$ & LCC & $-29,86$ & 0,1126 & 0,020 & 0,138 & 38 \\
\hline $13 C C p$ & $\mathrm{t}$ & $-19,78$ & 0,01087 & 0,366 & 0,023 & 36 \\
\hline $13 \mathrm{CUn}$ & $\mathrm{CCC}$ & $-23,16$ & 0,04712 & 0,414 & 0,020 & 35 \\
\hline $13 \mathrm{CUn}$ & LCC & $-31,69$ & 0,1354 & 0,045 & 0,113 & 35 \\
\hline $13 \mathrm{CUn}$ & $\mathrm{t}$ & $-20,10$ & 0,01710 & 0,332 & 0,029 & 33 \\
\hline $13 \mathrm{CNa}$ & $\mathrm{CCC}$ & $-23,16$ & 0,04712 & 0,414 & 0,020 & 35 \\
\hline $13 \mathrm{CNa}$ & LCC & $-25,36$ & 0,07289 & 0,101 & 0,069 & 39 \\
\hline $13 \mathrm{CNa}$ & $\mathrm{t}$ & $-20,10$ & 0,01710 & 0,332 & 0,029 & 33 \\
\hline $13 \mathrm{CAl}$ & $\mathrm{CCC}$ & $-16,56$ & $-0,00928$ & 0,818 & 0,001 & 37 \\
\hline $13 \mathrm{CAl}$ & LCC & $-20,90$ & 0,03303 & 0,491 & 0,013 & 37 \\
\hline $13 \mathrm{CAl}$ & $\mathrm{t}$ & $-17,92$ & 0,00316 & 0,767 & 0,002 & 37 \\
\hline $13 \mathrm{CVi}$ & $\mathrm{CCC}$ & $-20,35$ & 0,00900 & 0,775 & 0,002 & 37 \\
\hline $13 \mathrm{CVi}$ & LCC & $-23,35$ & 0,03941 & 0,292 & 0,031 & 37 \\
\hline $13 \mathrm{CVi}$ & $\mathrm{t}$ & $-19,68$ & 0,002757 & 0,741 & 0,003 & 37 \\
\hline $13 \mathrm{CCo}$ & $\mathrm{CCC}$ & $-17,53$ & 0,00623 & 0,874 & 0,001 & 37 \\
\hline $13 \mathrm{CCo}$ & LCC & $-19,78$ & 0,02904 & 0,533 & 0,011 & 37 \\
\hline $13 \mathrm{CCo}$ & $\mathrm{t}$ & $-17,79$ & 0,00842 & 0,414 & 0,019 & 37 \\
\hline
\end{tabular}

\subsection{Discussão}

A tartaruga-verde é uma espécie oportunista, com alta plasticidade de forrageamento, tanto para itens de dieta, que varia de acordo com a disponibilidade de alimento em cada ambiente (i.e., bentônico e pelágico) quanto para habitats de forrageamento (e.g., recifes, estuários, 
substrato não consolidado) (Santos et al 2015). A variabilidade de dieta pode ocorrer até mesmo entre indivíduos que vivem em habitats similares (Nagaoka et al. 2012). Chelonia mydas é conhecida por ser basicamente herbívora quando adulta. No entanto, diversos estudos têm demonstrado que, apesar de sua dieta ser composta na maioria dos casos por algas e gramas marinhas, ela também pode conter uma relevante presença de matéria animal como cnidários, moluscos e crustáceos (Seminoff et al. 2002, 2006a, López Mendilaharsu et al. 2005, Rodriguez Baron 2010, Santos et al. 2015, Vélez-Rubio et al. 2016)

A análise de variâncias (ANOVA) mostrou que a variância entre os valores de $\delta^{15} \mathrm{~N}$ das amostras (i.e., dos mesmos tecidos de diferentes fêmeas) é significativamente diferente da variância existente entre os tecidos diferentes. De acordo com a análise de médias de $\delta^{15} \mathrm{~N}$ (ANOM, Figura 3.2), a maioria dos tecidos apresenta média significativamente similar à média geral, mesmo comparando tecidos de metabolismo mais lento (e.g., queratina da carapaça) e mais acelerado (e.g., plasma). Apenas um tecido apresentou média maior que a média geral (i.e., epiderme) e dois apresentaram médias menores (i.e., sangue total e células vermelhas). Alguns estudos relatam a fidelidade individual de tartarugas marinhas ao habitat de forrageamento (Miller et al., 2003; Broderick et al. 2007; Shimada et al. 2014; Tucker et al. 2014). Se isso ocorrer, a fonte de recursos deve se manter similar e é possível que as tartarugas mais carnívoras se mantenham mais carnívoras ao longo do tempo, ocorrendo o mesmo com as mais herbívoras. Ceriani et al. (2014) verificaram que vitelo, células vermelhas, soro do sangue e epiderme são isotopicamente equivalentes e representam a assinatura isotópica do ambiente de forrageamento das fêmeas (i.e., quando ainda não migraram para as áreas de reprodução). Para analisar essa equivalência entre os tecidos do nosso estudo, verificamos a relação entre um tecido com valor abaixo da média, um com valor acima e outro dentro da média (i.e., células vermelhas, epiderme e plasma, Figura 3.2). Por meio de regressões lineares entre as possívieis combinações de pares desses três tecidos, verificamos a forte relação entre eles ( $\mathrm{r}^{2}$ entre 0,903 e 0,954 , Tabela 3.5). As diferenças apontadas na AMOM podem se dar devido às diferenças nos fatores de discriminação de cada tecido (ie., diferença entre os valores da tartaruga e da sua dieta). Devido aos processos bioquímicos diferenciados na renovação de cada tecido, alguns podem apresentar um enriquecimento ou empobrecimento dos isótopos de formas distintas, mesmo que o pool de recursos alimentares se mantenha ao longo do tempo.

Para o $\delta^{13} \mathrm{C}$, a análise de variâncias (ANOVA) também apontou que a variância entre os valores de amostras dos mesmos tecidos de diferentes fêmeas é significativamente diferente da variância existente entre os tecidos. De acordo com a ANOM (Figura 3.3), os mesmos tecidos apontados para $\delta^{15} \mathrm{~N}$ apresentaram valores acima ou abaixo da média geral, juntamente com o vitelo e a casca do ovo (Figura 3.3). Da mesma forma como fizemos com os valores de $\delta^{15} \mathrm{~N}$, verificamos a relação entre as médias de um tecido abaixo, um acima e um dentro da média geral (i.e., células vermelhas, epiderme e plasma). Também encontramos para o $\delta^{13} \mathrm{C}$ forte relação entre 
os tecidos ( $\mathrm{r}^{2}$ variando entre 0,892 e 0,927 , Tabela 3.6). Assim, a fonte de carbono também parece não variar. Os fatores de discriminação do $\delta^{15} \mathrm{~N}$ e do $\delta^{13} \mathrm{C}$ podem ser diferentes para um mesmo tecido (Vander Zanden et al. 2012) e, possivelmente, por isso o vitelo e a casca do ovo apresentaram médias diferentes da média geral para o $\delta^{13} \mathrm{C}$, mas similares para o $\delta^{15} \mathrm{~N}$.

O consumo de matéria animal ou a inclusão de itens animais na alimentação tendem a aumentar os valores de $\delta^{15} \mathrm{~N}$, devido ao enriquecimento do isótopo em relação à sua dieta (Minigawa \& Wada 1984). Dessa forma, verificando-se variação de $\delta^{15} \mathrm{~N}$ entre as fêmeas, é possível compará-las em relação aos níveis tróficos ocupados. Devido à atividade metabólica diferenciada de cada tecido, o período de tempo que cada um leva para refletir a dieta consumida também varia. Por isso, informações obtidas de tecidos com velocidades de metabolismo distintos, apresentam taxas de renovação diferentes (turnover), fornecendo informações temporais diferentes a respeito da dieta (Vander Zanden et al. 2013; Ceriani et al. 2014). Tecidos inertes, como queratina e epiderme, levam mais tempo para se renovarem, apresentando turnover mais elevado. A queratina da carapaça posterior de fêmeas adultas de C. mydas fornece informação de 2,4 a 6,5 anos (Vander Zanden et al. 2013). Essa, possivelmente, é a informação mais antiga que coletamos, já que as camadas de queratina se acumulam ao longo do tempo e a região posterior fica mais espessa (Reich et al. 2007; Vader Zanden et al. 2010). Não encontramos informações sobre o turnover dos outros tecidos para tartarugas adultas, mas em estudo com jovens de $C$. caretta, que provavelmente apresentam renovação do tecido mais rápida, a ordem crescente de turnover para alguns tecidos aqui coletados foram: plasma, sangue total, células vermelhas e epiderme (Reich et al. 2008). Esses tecidos variaram na ordem de semanas a pouco mais de um mês. É provável que para indivíduos adultos esses valores sejam maiores. Assim, por meio da AIE, acreditamos estar abrangendo nesse trabalho uma ampla informação temporal a respeito do nível trófico das fêmeas, que pode variar de poucos meses a algo em torno de seis anos e meio.

Apesar de muitos tecidos não apresentarem diferenças significativas, tanto para a $\delta^{15} \mathrm{~N}$, quanto para a $\delta^{13} \mathrm{C}$, não podemos substituir a análise de um tecido pela de outro baseado apenas nos gráficos da ANOM. As Figuras 3.6, 3.7 e 3.8 mostram que as relações do $\delta^{15} \mathrm{~N}$ com cada variável (CCC, LCC e tamanho da ninhada) diferem entre os tecidos. Como exemplo, podemos observar o caso do albúmen e da carapaça posterior que, de acordo com a ANOM de $\delta^{15} \mathrm{~N}$, não são significativamente diferentes. No entanto, o $\delta^{15} \mathrm{~N}$ da carapaça posterior é altamente relacionado com a $\operatorname{LCC}\left(\mathrm{r}^{2}=0,307\right.$, Figura $\left.5 \mathrm{~d}\right)$, ao passo que não há relação significativa entre $\delta^{15} \mathrm{~N}$ do albúmen e essa variável (Tabela 3.7).

Alguns estudos que envolvem AIE fornecem equações de conversão que permitem a inferência de valores de $\delta^{15} \mathrm{~N}$ e $\delta^{13} \mathrm{C}$ de um determinado tecido a partir das informações disponíveis de um outro tecido (Petitet \& Bugoni 2017). Dessa forma, se um pesquisador dispuser de valores de um tecido e quiser obter os valores de outro sem que o tenha coletado, é possível 
inferir esses valores caso esteja disponível uma equação de conversão entre estes dois tecidos. Neste trabalho, fornecemos equações de conversão entre os seguintes tecidos: plasma, carapaça anterior e casca do ovo (Tabelas 3.1 e 3.2). Diversas relações foram testadas com $\delta^{15} \mathrm{~N}$ e $\delta^{13} \mathrm{C}$ de componentes do ovo, o qual pode ser facilmente coletado quando se consegue presenciar a fêmea desovando. Quando é coletado o sangue desses animais, alguns estudos analisam a composição isotópica do sangue total e outros separam os componentes (plasma e células vermelhas). Quando há a separação, normalmente são obtidas amostras dos dois componentes, no entanto, os custos das análises aumentam. Dessa forma, as equações fornecidas nas Tabelas 3.3 e 3.4 podem ser úteis. Aconselhamos, sempre que possível, a utilização das equações com maiores coeficientes de determinação.

Como principal objetivo deste estudo, verificamos a relação entre $\delta^{15} \mathrm{~N}$ com o tamanho corporal das fêmeas e de suas ninhadas. Vimos que fêmeas de níveis tróficos mais elevados tendem a ser maiores e a produzirem mais ovos. É importante salientar que para todos os 12 tecidos analisados houve alta relação positiva entre $\delta^{15} \mathrm{~N}$ e o tamanho da ninhada, sugerindo que a posição trófica da fêmea de fato interfere no seu investimento reprodutivo. Ao que parece, as tartarugas de níveis tróficos mais altos, ou seja, que incluem itens alimentares de fonte animal em sua dieta (e.g., lulas, crustáceos, águas-vivas), tendem a ser maiores e a produzirem maior quantidade de ovos. Os valores de $\delta^{15} \mathrm{~N}$ devem aumentar quanto maior for a contribuição animal na dieta dos indivíduos. É possível que parte dos indivíduos ingiram outros itens menores de forma não intencional, aderidos às algas, por exemplo (Santos et al. 2015). De qualquer forma, esses itens irão refletir nos valores tanto de $\delta^{15} \mathrm{~N}$ quanto de $\delta^{13} \mathrm{C}$ de seus tecidos.

Santos et al. (2015) coletaram dados de dieta de 137 tartarugas-verdes ao longo da costa brasileira por meio de lavagem esofágica para indivíduos vivos e coleta de conteúdo esofágico e estomacal de indivíduos mortos. Somado a esses dados, compilaram dados de dieta, quase todos coletados no Brasil, de 290 indivíduos de C. mydas obtidos de estudos publicados. Os autores verificaram que a contribuição animal na dieta dessa espécie é elevada e intencional em áreas de baixas temperaturas (entre isotermas de $10^{\circ}$ e $20^{\circ} \mathrm{C}$ ), onde as assembleias de algas são mais pobres. A ingestão de itens animais em regiões acima da isoterma de $20^{\circ} \mathrm{C}$ foi considerada acidental, de pequenos invertebrados aderidos às algas. Os autores atribuem esses resultados a fatores intrínsecos e extrínsecos à espécie. Limitações fisiológicas de animais ectotérmicos podem fazer com que, nessas regiões mais frias, a digestão de itens vegetais seja dificultada e, com isso, o aporte animal seja maior, devido à sua melhor digestão e ao seu maior fornecimento de energia. A variação regional na composição das assembleias de algas e maior disponibilidade animal nesses ambientes também foram consideradas na explicação da contribuição animal na dieta em estuários de águas frias.

Tomaszewicz et al. (2018) realizaram estudo com amostras de úmero e epiderme de tartarugas-verdes na costa oeste do México, utilizando técnica de esqueletocronologia para 
determinação de idade e AIE para determinação de uso de recursos. Os autores propõem que essas tartarugas sejam forrageiras pelágicas de longo prazo, consumindo dieta mais carnívora na zona epipelágica, e possivelmente peixes descartados da pesca demersal. Os autores ainda sugerem que esse forrageamento possa beneficiar o aumento do crescimento somático. O estudo apresenta uma exploração inesperada de habitat e presas por tartarugas-verdes de fase pós-oceânica, quando são conhecidas por serem herbívoras neríticas.

Segundo Paéz-Rosa et al. (2012), a estratégia de forrageamento de predadores marinhos pode variar, de acordo com a pressão de competição interespecífica a que estão submetidos e às suas características morfológicas e fisiológicas. Em muitas regiões de sua ocorrência, a tartarugaverde ocorre em simpatria com outras espécies de tartarugas marinhas e com outras espécies que podem se alimentar de parte do conjunto de itens alimentares que compõem a dieta da C. mydas. É possível que, em determinadas regiões geográficas, onde a intensidade da competição por recursos seja reduzida, fêmeas adultas de $C$. mydas apresentem maior proporção animal em sua dieta, ou em que a disponibilidade dessa seja maior.

Um fator que deve ser considerado nesse estudo é que ambientes diferentes podem apresentar organismos de linha de base isotopicamente distintos (baseline) (Michener \& Lajtha 2007). Esses organismos são os produtores na cadeia trófica. Se em regiões diferentes são encontrados valores muito distintos de $\delta^{15} \mathrm{~N}$ para os produtores, os consumidores também apresentarão esses valores distintos entre essas regiões, porque os consumidores geralmente são enriquecidos em $\delta^{15} \mathrm{~N}$ em relação à sua dieta (Minigawa \& Wada 1984). Dessa forma, quando comparamos valores de $\delta^{15} \mathrm{~N}$ de indivíduos que se alimentam em áreas de baseline diferentes, essa diferença pode estar ocorrendo não pelos níveis tróficos distintos, mas sim pela diferença nos valores de $\delta^{15} \mathrm{~N}$ dos organismos de linha de base. Isso faz com que os indivíduos da mesma espécie e de mesmo nível trófico, mas de regiões diferentes, apresentem valores discrepantes em relação ao $\delta^{15} \mathrm{~N}$. Essa é uma situação que deve ser considerada neste estudo. Todas as fontes de nitrogênio $(\mathrm{N})$ que alcançam o mar podem alterar a linha de base $\delta^{15} \mathrm{~N}$ da biota marinha (escoamento terrestre, deposição atmosférica, $\mathrm{NO}_{3}{ }^{-}$e fixação de $\mathrm{N}_{2}$ ) (Michener \& Lajtha 2007). No entanto, a matéria animal é considerada uma fonte de alimentação de maior qualidade, com conteúdo nutricional e energético maiores (Newman 2007). Por isso, uma dieta com maior valor proteico, parece ser muito mais plausível para justificar maiores tamanhos de fêmeas (com maiores $\delta^{15} \mathrm{~N}$ ), e de suas ninhadas, do que altos valores de $\delta^{15} \mathrm{~N}$ causados pelas fontes citadas acima.

No que se refere ao $\delta^{13} \mathrm{C}$, houve relação significativa, porém baixa (maior coeficiente de determinação, $\mathrm{r}^{2}$, foi de 0,149$)$, de somente quatro tecidos com apenas uma das variáveis examinadas (i.e., largura curvilínea da carapaça). Desta forma, a fonte de carbono não parece influenciar nas variáveis aqui examinadas (CCC, LCC e tamanho da ninhada). 
Confirmamos a relação do nível trófico das fêmeas com o tamanho de sua ninhada. No entanto, não conhecemos suas áreas de alimentação. Para planos de conservação dessa espécie, é de suma importância que se tenha informações sobre o local onde se alimentam as tartarugas que mais contribuem com a reprodução (i.e., maiores e mais carnívoras). Sugerimos, então, estudos que busquem identificar os habitats de alimentação dessas fêmeas, possivelmente utilizando-se ferramentas conjuntas, como telemetria por satélite e análise de isótopos estáveis. O uso de telemetria por satélite em fêmeas após a nidificação possibilita a determinação de suas áreas de alimentação, pois essas tendem a voltar à área de forrageamento após a reprodução (Broderick et al. 2007). Dessa forma, é possível verificar a relação entre o local onde essas fêmeas se alimentam e suas assinaturas isotópicas (Hatase et al. 2006). Confirmada a relação, essa informação permite, através da AIE, inferir os locais de forrageamento das demais fêmeas, não monitoradas por telemetria. Recomendamos, também, estudos que abranjam AIE de itens alimentares potenciais da espécie para inferência de tipo de habitat de alimentação (nerítico vs oceânico).

Há, na literatura, escassez de informação sobre as taxas de turnover (tempo que um tecido leva para refletir isotopicamente sua dieta) e o fator de discriminação (diferença entre o valor de $\delta^{15} \mathrm{~N}$ e $\delta^{13} \mathrm{C}$ do animal e o valor de $\delta^{15} \mathrm{~N}$ e $\delta^{13} \mathrm{C}$ da dieta) de isótopos estáveis de tartaruga-verde. Estudos que utilizam análise de isótopos estáveis (Ceriani et al. 2014) frequentemente esbarram nessa lacuna de conhecimento, como é o caso do presente estudo, o que por vezes limita a interpretação dos resultados. O enriquecimento de um nível trófico para outro de $\delta^{15} \mathrm{~N}$, por exemplo, em geral ocorre em torno de 3,4\%. No entanto, em estudo realizado por Seminoff et al. (2006b) com oito indivíduos de C. mydas em cativeiro sob dieta controlada, esse valor variou de $+0,22 \%$ (células vermelhas do sangue) a $+2,92 \%$ (plasma sanguíneo). No Brasil, o Projeto TAMAR/ICMBio, referência em pesquisa e conservação de tartarugas marinhas no país, possui em seus centros de visitantes indivíduos adultos que possivelmente poderiam ser utilizados em estudos com essa finalidade.

\subsection{Conclusão}

Fêmeas que incluem matéria animal em sua dieta, ou seja, aquelas de níveis tróficos mais elevados (i.e., maiores valores de $\delta^{15} \mathrm{~N}$ ) são maiores e produzem mais ovos. A fonte de carbono parece não influenciar no tamanho corporal e na reprodução das fêmeas.

Recomendamos estudos que esclareçam sobre as áreas de alimentação das fêmeas, sobretudo daquelas de maior tamanho corporal e maior nível trófico. Recomendamos, também, experimentos controlados com indivíduos em cativeiro para determinação de taxas de turnover e de fatores de discriminação dos diferentes tecidos. 


\section{Referências bibliográficas}

Araújo, M. S., Bolnick, D. I., Machado, G., Giaretta, A. A., \& Dos Reis, S. F. (2007). Using $\delta 13$ $\mathrm{C}$ stable isotopes to quantify individual-level diet variation. Oecologia, 152(4), 643-654.

Bjorndal, K. A. (1997). Foraging ecology and nutrition of sea turtles. The biology of sea turtles, 1 , 199-231.

Bjorndal, K. A., \& Carr, A. (1989). Variation in clutch size and egg size in the green turtle nesting population at Tortuguero, Costa Rica. Herpetologica, 181-189.

Broderick, A. C., Glen, F., Godley, B. J., \& Hays, G. C. (2003). Variation in reproductive output of marine turtles. Journal of Experimental Marine Biology and Ecology, 288(1), 95-109.

Broderick, A. C., Coyne, M. S., Fuller, W. J., Glen, F., \& Godley, B. J. (2007). Fidelity and overwintering of sea turtles. Proceedings of the Royal Society of London B: Biological Sciences, 274(1617), 1533-1539.

Ceriani, S. A., Roth, J. D., Ehrhart, L. M., Quintana-Ascencio, P. F., \& Weishampel, J. F. (2014). Developing a common currency for stable isotope analyses of nesting marine turtles. Marine biology, 161(10), 2257-2268.

DeNiro, M.J. \& Epstein, S. (1981). Influence of Diet on the Distribution of Nitrogen Isotopes in Animals. Geochimica et Cosmochimica Acta. 45. 341-351.

Carman, V. G., Botto, F., Gaitán, E., Albareda, D., Campagna, C., \& Mianzan, H. (2014). A jellyfish diet for the herbivorous green turtle Chelonia mydas in the temperate SW Atlantic. Marine biology, 161(2), 339-349.

Hatase, H., Takai, N., Matsuzawa, Y., Sakamoto, W., Omuta, K., Goto, K., Arai, N. \& Fujiwara, T. (2002). Size-related differences in feeding habitat use of adult female loggerhead turtles Caretta caretta around Japan determined by stable isotope analyses and satellite telemetry. Marine Ecology Progress Series, 233, 273-281.

Hatase, H., Sato, K., Yamaguchi, M., Takahashi, K., \& Tsukamoto, K. (2006). Individual variation in feeding habitat use by adult female green sea turtles (Chelonia mydas): are they obligately neritic herbivores?. Oecologia, 149(1), 52-64.

Hatase, H., Omuta, K., \& Tsukamoto, K. (2013). A mechanism that maintains alternative life histories in a loggerhead sea turtle population. Ecology, 94(11), 2583-2594.

Kaufman, T. J., Pajuelo, M., Bjorndal, K. A., Bolten, A. B., Pfaller, J. B., Williams, K. L., \& Vander Zanden, H. B. (2014). Mother-egg stable isotope conversions and effects of lipid extraction and ethanol preservation on loggerhead eggs. Conservation physiology, 2(1).

Lemons, G. E., Eguchi, T., Lyon, B. N., LeRoux, R., \& Seminoff, J. A. (2012). Effects of blood anticoagulants on stable isotope values of sea turtle blood tissue. Aquatic Biology, 14(3), 201206.

López-Mendilaharsu, M., Gardner, S. C., Seminoff, J. A., \& Riosmena-Rodriguez, R. (2005). Identifying critical foraging habitats of the green turtle (Chelonia mydas) along the Pacific 
coast of the Baja California peninsula, Mexico. Aquatic conservation: Marine and freshwater ecosystems, 15(3), 259-269.

Michener, R., \& Lajtha, K. (Eds.). (2007). Stable isotopes in ecology and environmental science. John Wiley \& Sons.

Miller, J. D., Limpus, C. J., \& Godfrey, M. H. (2003). Nest site selection, oviposition, eggs, development, hatching, and emergence of loggerhead turtles. Loggerhead sea turtles, 12.

Minigawa, M., \& Wada, E. (1984). Stepwise enrichment of $15 \mathrm{~N}$ along food chains: further evidence and the relation between $\delta 15 \mathrm{~N}$ and animal age. Geochim Cosmochim Acta, $48(1)$, $135-1$.

Nagaoka, S. M., Martins, A. S., Dos Santos, R. G., Tognella, M. M. P., de Oliveira Filho, E. C., \& Seminoff, J. A. (2012). Diet of juvenile green turtles (Chelonia mydas) associating with artisanal fishing traps in a subtropical estuary in Brazil. Marine biology, 159(3), 573-581.

Newman, J. (2007). Herbivory. In: Stephens, D.W., Brown, J.S., and Ydenberg, R.C. (Eds.). Foraging: Behavior and Ecology. Chicago: University of Chicago Press, pp. 175-220.

Reich, K. J., Bjorndal, K. A., \& Bolten, A. B. (2007). The 'lost years' of green turtles: using stable isotopes to study cryptic lifestages. Biology letters, 3(6), 712-714.

Páez-Rosas, D., Aurioles-Gamboa, D., Alava, J. J., \& Palacios, D. M. (2012). Stable isotopes indicate differing foraging strategies in two sympatric otariids of the Galapagos Islands. Journal of Experimental Marine Biology and Ecology, 424, 44-52.

Parker, D. M., Dutton, P. H., \& Balazs, G. H. (2011). Oceanic diet and distribution of haplotypes for the green turtle, Chelonia mydas, in the Central North Pacific. Pacific Science, 65(4), 419431.

Petitet, R., \& Bugoni, L. (2017). High habitat use plasticity by female olive ridley sea turtles (Lepidochelys olivacea) revealed by stable isotope analysis in multiple tissues. Marine Biology, 164(6), 134.

Post, D. M. (2002). Using stable isotopes to estimate trophic position: models, methods, and assumptions. Ecology, 83(3), 703-718.

Post, D. M., Layman, C. A., Arrington, D. A., Takimoto, G., Quattrochi, J., \& Montana, C. G. (2007). Getting to the fat of the matter: models, methods and assumptions for dealing with lipids in stable isotope analyses. Oecologia, 152(1), 179-189.

Reich, K. J., Bjorndal, K. A., \& Bolten, A. B. (2007). The 'lost years' of green turtles: using stable isotopes to study cryptic lifestages. Biology letters, 3(6), 712-714.

Reich, K. J., Bjorndal, K. A., \& Del Rio, C. M. (2008). Effects of growth and tissue type on the kinetics of $13 \mathrm{C}$ and $15 \mathrm{~N}$ incorporation in a rapidly growing ectotherm. Oecologia, 155(4), 651-663. 
Rodríguez Barón, J. M. (2010). Afinidad trófica a zonas de alimentación de la tortuga verde (Chelonia mydas) en la costa occidental de Baja California Sur, México (Doctoral dissertation, Instituto Politécnico Nacional. Centro Interdisciplinario de Ciencias Marinas).

Santos, R. G., Martins, A. S., Batista, M. B., \& Horta, P. A. (2015). Regional and local factors determining green turtle Chelonia mydas foraging relationships with the environment. Marine Ecology Progress Series, 529, 265-277.

Seminoff, J. A., Resendiz, A., \& Nichols, W. J. (2002). Diet of East Pacific green turtles (Chelonia mydas) in the central Gulf of California, Mexico. Journal of Herpetology, 36(3), 447-453.

Seminoff, J. A., Jones, T. T., \& Marshall, G. J. (2006a). Underwater behaviour of green turtles monitored with video-time-depth recorders: what's missing from dive profiles?. Marine Ecology Progress Series, 322, 269-280.

Seminoff, J. A., Jones, T. T., Eguchi, T., Jones, D. R., \& Dutton, P. H. (2006b). Stable isotope discrimination ( $\delta 13 \mathrm{C}$ and $\delta 15 \mathrm{~N}$ ) between soft tissues of the green sea turtle Chelonia mydas and its diet. Marine Ecology Progress Series, 308, 271-278.

Shimada, T., Aoki, S., Kameda, K., Hazel, J., Reich, K., \& Kamezaki, N. (2014). Site fidelity, ontogenetic shift and diet composition of green turtles Chelonia mydas in Japan inferred from stable isotope analysis. Endangered Species Research, 25(2), 151-164.

Tomaszewicz, C. N. T., Seminoff, J. A., Avens, L., Goshe, L. R., Rguez-Baron, J. M., Peckham, S. H., \& Kurle, C. M. (2018). Expanding the coastal forager paradigm: long-term pelagic habitat use by green turtles Chelonia mydas in the eastern Pacific Ocean. Marine Ecology Progress Series, 587, 217-234.

Tucker, A. D., MacDonald, B. D., \& Seminoff, J. A. (2014). Foraging site fidelity and stable isotope values of loggerhead turtles tracked in the Gulf of Mexico and northwest Caribbean. Marine Ecology Progress Series, 502, 267-279.

Vander Zanden, H. B., Bjorndal, K. A., Reich, K. J., \& Bolten, A. B. (2010). Individual specialists in a generalist population: results from a long-term stable isotope series. Biology letters, 6(5), 711-714.

Vander Zanden, H. B., Bjorndal, K. A., Mustin, W., Ponciano, J. M., \& Bolten, A. B. (2012). Inherent variation in stable isotope values and discrimination factors in two life stages of green turtles. Physiological and Biochemical Zoology, 85(5), 431-441.

Vander Zanden, H. B., Bjorndal, K. A., \& Bolten, A. B. (2013). Temporal consistency and individual specialization in resource use by green turtles in successive life stages. Oecologia, 173(3), 767-777.

Vélez-Rubio, G. M., Cardona, L., López-Mendilaharsu, M., Souza, G. M., Carranza, A., González-Paredes, D., \& Tomás, J. (2016). Ontogenetic dietary changes of green turtles (Chelonia mydas) in the temperate southwestern Atlantic. Marine biology, 163(3), 57. 
Vieira, S., Martins, S., Hawkes, L. A., Marco, A., \& Teodósio, M. A. (2014). Biochemical indices and life traits of loggerhead turtles (Caretta caretta) from Cape Verde Islands. PloS one, $9(11), \mathrm{e} 112181$. 


\section{Considerações finais}

No presente estudo, buscamos encontrar um perfil de fêmeas nidificantes de Chelonia mydas, em relação ao seu tamanho e à sua posição trófica, que mais contribui com a reprodução da espécie. Para isso, verificamos a possível relação entre tamanho da fêmea e seu investimento reprodutivo e a relação do seu nível trófico com o seu tamanho e o tamanho de sua ninhada.

No capítulo 2, verificamos que fêmeas maiores (maiores CCC e LCC) tendem a produzir ninhadas e ovos maiores. Para isso, consideramos o comprimento e a largura curvilíneos da carapaça (CCC e LCC, respectivamente) como medidas de tamanho corporal das fêmeas. Como proxi do investimento reprodutivo das fêmeas, usamos o tamanho da ninhada (i.e. número de ovos) e o tamanho dos ovos (i.e., diâmetro e massa dos ovos). Fornecemos equações para inferir tamanho de ninhada a partir do tamanho corporal (CCC e LCC) e recomendamos a equação que utiliza o CCC, já que essa apresenta maior coeficiente de determinação $\left(r^{2}=0,469\right)$. Além disso, analisamos a relação entre o tamanho da fêmea e o seu rastro marcado na areia. Verificamos que fêmeas maiores produzem rastros mais largos e fornecemos equações para inferir o tamanho das fêmeas a partir da largura de seus rastros. O monitoramento e registros desses rastros são comuns em praias de desova e relativamente fáceis e baratos de se realizar. A utilização dessas equações pode fornecer informações úteis nas avaliações de oscilações populacionais de tamanhos das fêmeas nas praias de nidificação e na priorização de praias para proteção dos ninhos. Recomendamos também uma possível compilação dos dados do projeto TAMAR/ICMBio para auxiliar na identificação dos locais onde as fêmeas maiores nidificam e onde os maiores indivíduos se alimentam.

No capítulo 3, sugerimos que tartarugas com tendência à maior carnivoria mantenham esse hábito alimentar ao longo do tempo, assim como as mais herbívoras. Verificamos que fêmeas de níveis tróficos mais elevados são maiores e contribuem mais com a reprodução, produzindo mais ovos. A fonte de carbono parece não influenciar nas variáveis analisadas (CCC, LCC e tamanho da ninhada). Fornecemos equações com altos coeficientes de determinação $\left(\mathrm{r}^{2}\right)$ para conversão de valores de $\delta^{15} \mathrm{~N}$ e $\delta^{13} \mathrm{C}$ entre alguns tecidos, mostrando-se bem ajustadas aos dados coletados. Propusemos estudos que esclareçam sobre as áreas de alimentação das fêmeas, a fim de se identificar onde vivem as fêmeas que mais contribuem com a reprodução (i.e., maiores e mais carnívoras). Sugerimos também estudos com indivíduos em cativeiro para determinação de taxas de turnover e fatores de discriminação de diferentes tecidos, uma vez que esses dados são escassos e limitam interpretações de resultados. 